\title{
Knockdown of Prodynorphin Gene Prevents Cognitive Decline, Reduces Anxiety, and Rescues Loss of Group 1 Metabotropic Glutamate Receptor Function in Aging
}

\author{
Caroline Ménard, ${ }^{1}$ Yiu Chung Tse, ${ }^{1}$ Chelsea Cavanagh, ${ }^{1}$ Jean-Guy Chabot, ${ }^{1}$ Herbert Herzog,,${ }^{2}$ Christoph Schwarzer, ${ }^{3}$ \\ Tak Pan Wong, ${ }^{1}$ and Rémi Quirion ${ }^{1}$ \\ ${ }^{1}$ Douglas Mental Health University Institute, McGill University, Montreal, Quebec H4H 1R3, Canada, ${ }^{2}$ Garvan Institute of Medical Research, University of \\ New South Wales, Sydney, New South Wales, Australia 2010, and ${ }^{3}$ Department of Pharmacology, Innsbruck Medical Institute, Innsbruck, Austria 6020
}

Expression of dynorphin, an endogenous opioid peptide, increases with age and has been associated with memory impairments in rats. In human, prodynorphin $(P d y n)$ gene polymorphisms might be linked to cognitive function in the elderly. Moreover, elevated dynorphin levels have been reported in postmortem samples from Alzheimer's disease patients. However, the cellular and molecular processes affected by higher dynorphin levels during aging remain unknown. Using $P d y n^{-1-}$ mice, we observed significant changes in the function and expression of Group 1 metabotropic glutamate receptor (mGluR). Compared with age-matched wild-type (WT) littermates, we found increased expression of mGluR1 $\alpha$ and mGluR5 in the hippocampus and cortex of old, but not young, Pdyn ${ }^{-1-}$ mice. Increased Group 1 mGluR expression in aged $P d y n^{-1-}$ mice was associated with enhanced mGluR-mediated long-term depression, a form of synaptic plasticity. Notably, whereas aged WT mice developed spatial and recognition memory deficits, aged $P d y n^{-1-}$ mice performed similarly as young mice. Pharmacological treatments with 3-cyano-N-(1,3-diphenyl-1H-pyrazol-5-yl)benzamide, a positive modulator of mGlu5 receptors, or norbinaltorphimine, an antagonist for dynorphin-targeted $\kappa$-opioid receptor, rescued memory in old WT mice. Conversely, mGlu5 receptor antagonist 2-methyl-6-(phenylethynyl)pyridine hydrochloride impaired spatial memory of old Pdyn ${ }^{-1-}$ mice. Intact cognition in aged $P \mathrm{dyn}^{-1-}$ mice paralleled with increased expression of Group $1 \mathrm{mGluR}$-related genes Homer $1 \mathrm{a}$ and Arc. Finally, aged $P d y n^{-1-}$ mice displayed less anxiety-related behaviors than age-matched WT mice. Together, our results suggest that elevated Pdyn expression during normal aging reduces mGluR expression and signaling, which in turn impairs cognitive functions and increases anxiety.

\section{Introduction}

Aging is generally characterized by reduced cognitive abilities and heightened anxiety-related behaviors (Bedrosian et al., 2011). Increasing findings suggest that age-related cognitive and emotional dysfunctions are related to rising dynorphins in the aged brain (Yakovleva et al., 2007; Kolsch et al., 2009). Dynorphins, a class of centrally expressed opioids peptides that are encoded by the prodynorphin $(P d y n)$ gene, have been related to learning and memory processes, emotional control, and stress response (Schwarzer, 2009). Expression of dynorphins increases with age, and this upregulation has been associated with memory impair-

Received Jan. 21, 2013; revised May 16, 2013; accepted June 25, 2013.

Author contributions: C.M., T.P.W., and R.Q. designed research; C.M., Y.C.T., C.C., and J.-G.C. performed research; H.H. and C.S. contributed unpublished reagents/analytic tools; C.M., Y.C.T., C.C., J.-G.C., and T.P.W. analyzed data; C.M., H.H., C.S., T.P.W., and R.Q. wrote the paper.

This work was supported by Canadian Institutes of Health Research grants to R.Q. and T.P.W., C.M. is the recipient of a Fellowship from Canadian Institutes of Health Research. We thank Eve-Marie Charbonneau, Dr. Joseph Rochford, and Dr. Salah El Mestikawy for technical assistance and advice, and Dr. John Breitner for his scientific input.

The authors declare no competing financial interests.

Correspondence should be addressed to either Dr. Rémi Quirion or Dr. Tak Pan Wong, Douglas Mental Health University Institute, Perry Pavilion, 6875 LaSalle Boulevard, Montréal, Quebec, Canada H4H 1R3, E-mail: remi.quirion@frq.gouv.qc.ca or takpan.wong@mcgill.ca.

DOI:10.1523/JNEUROSCI.0290-13.2013

Copyright $\odot 2013$ the authors $\quad 0270-6474 / 13 / 3312792-13 \$ 15.00 / 0$ ments in rats (Jiang et al., 1989; Kotz et al., 2004). In human, $P d y n$ gene polymorphisms might be linked with episodic memory deficits in the elderly (Kolsch et al., 2009) and elevated dynorphin expression could be involved in the pathogenesis of Alzheimer's disease (Yakovleva et al., 2007).

Maintenance of intact cognition during aging could require an adaptation of synaptic plasticity processes, which underlie memory formation. Acquisition and consolidation of spatial memory depend partly on Group 1 metabotropic glutamate receptor (mGluR) function in aged rats (Lee et al., 2005; Ménard and Quirion, 2012b). These receptors are enriched in the hippocampus, a brain area involved in cognition and stress responsivity (Squire, 1992; McEwen, 1999). Activation of Group 1 mGluR leads to long-term depression (LTD), a form of synaptic plasticity involved in goal directed behavior, novelty detection, and recognition memory formation (Luscher and Huber, 2010). LTD is crucial for developing effective neuronal network connections and facilitating spatial cognitive map generation (Kemp and Manahan-Vaughan, 2007; Malleret et al., 2010). Immediate early gene (IEG) translation is induced by mGluR activation and necessary for memory consolidation (Ménard and Quirion, 2012a). Gene expression has been targeted to explain memory deficits related to aging (Benoit et al., 2011). Increased expression 
of dynorphins in aged brain could affect cognition and emotional behaviors by impairing glutamatergic transmission. Both exogenously applied and endogenously released dynorphins weaken glutamatergic neurotransmission and long-term potentiation (Wagner et al., 1993). Activation of $\kappa$-opioid receptor (KOR), a postsynaptic receptor of dynorphins, suppresses presynaptic glutamate release (Simmons et al., 1994). Furthermore, KOR activation mediates stress-induced memory deficits (Carey et al., 2009). Notably, Group 1 mGluR activation increases Pdyn expression (Mao and Wang, 2001), suggesting a tight interaction between these systems. These findings raise a possibility that alteration of $P d y n$ could affect mGluR function and cognitive processes in aged brain.

In the current study, we evaluated whether deletion of $P d y n$ gene affects mGluR expression and function, memory formation, and anxiety during aging using $P d y n$ knock-out mice (Loacker et al., 2007). We observed an increase in Pdyn expression in the hippocampus and cortex of wild-type (WT) mice with aging. Group 1 mGluR protein level and function and related IEG expression were significantly enhanced in aged $P d y n^{-1-}$ mice compared with WT. Although old WT mice developed cognitive deficits in the Morris Water Maze (MWM) and novel object recognition (NOR) task, memory processes were intact in old $P d y n^{-1-}$ mice. Finally, anxiety-related behaviors increased with age in WT but not in $P d y n^{-1-}$ mice.

\section{Materials and Methods}

Mouse breeding. Heterozygous $P d y n^{+/-}$mice (C57BL/6N background; obtained from Dr. Christoph Schwarzer) (Loacker et al., 2007) were bred to generate the $\mathrm{F} 1$ generation of $P d y n^{+/+}, P d y n^{+/-}$, and $P d y n^{-/-}$mice. $P d y n^{+/+}$littermates were used as WT controls. Animals were housed up to five per cage and maintained on a $12 \mathrm{~h}$ light/dark cycle with ad libitum access to food (Purina Lab Chow; Mondou) and water in the Douglas Institute animal facility until 6, 12, or 18-25 months old. Animal care, surgery, and handling procedures were approved by the McGill University Animal Care Committee. Male mice were killed within a month after behavioral training for biochemical and electrophysiological analyses.

Mouse genotyping. DNA from mice ears was extracted using HotSHOT genomic DNA preparation. The genotype of mice was determined by PCR using Pdyn primers (5'-GGCTTCTCATCTTTTCTCACCC- 3 ' and 5'-TCACCACCTTGAACTGACGC-3') situated on exon 4 of the Pdyn gene and Cre primers (5'-CCACGACCAAGTGACAGCAATG- $3^{\prime}$ and $5^{\prime}$-AAGTGCCTTCTCTACACCTGCG-3') situated on the Cre-recombinase sequence, with 38 cycles of $94^{\circ} \mathrm{C}$ for $45 \mathrm{~s}, 57^{\circ} \mathrm{C}$ for $45 \mathrm{~s}$, and $72^{\circ} \mathrm{C}$ for $60 \mathrm{~s}$. $P d y n^{-1-}$ will produce a band of $327 \mathrm{bp}$ with Cre primers, whereas a band will be detected at $550 \mathrm{bp}$ for WT with $P d y n$ primers.

Drugs used for behavioral experiments. Norbinaltorphimine dihydrochloride (norBNI), 3-cyano-N-(1,3-diphenyl-1H-pyrazol-5-yl)benzamide (CDPPB), and 2-methyl-6-(phenylethynyl)pyridine hydrochloride (MPEP) were purchased from Tocris Bioscience. Drugs were dissolved in D-methylsulfoxide (DMSO, Sigma-Aldrich). CDPPB, MPEP, norBNI, and DMSO controls were diluted in saline solution ( $5 \%$ final concentration of DMSO) and administered intraperitoneally $20 \mathrm{~min}$ before behavioral training. All drugs were given at $10 \mathrm{mg} / \mathrm{kg}$ (Christoffersen et al., 2008; Uslaner et al., 2009; Munro et al., 2012; Smith et al., 2012).

Novel object recognition. This task evaluates episodic and reference memory. To reduce stress associated to a novel environment, mice were first exposed to an empty arena for $5 \mathrm{~min}$ (day 0 ). All the experiments were conducted under red light to facilitate object interaction and reduce stress. On day 1, the mouse was allowed to interact with two identical objects (familiar) for $5 \mathrm{~min}$. Sixty minutes later, the animal was reintroduced in the arena $(50 \mathrm{~cm} \times 50 \mathrm{~cm})$ with a familiar object and a novel object for $5 \mathrm{~min}$. The position of the objects was always the same in the arena to remove any spatial memory parameter from the task. On day 2 (24 h later), the mouse was exposed again to the familiar object and another novel object for $5 \mathrm{~min}$. After a $5 \mathrm{~min}$ delay, the animal was exposed once more to the familiar object and another novel object for 5 min. Unless otherwise specified, all experiments were digitally recorded for offline analysis using a tracking system Top Scan 2.0 (Clever Systems). Both the distance traveled and interaction time with objects of studied mice were examined.

Elevated plus maze. On day 3, the animals were tested for $5 \mathrm{~min}$ in an elevated plus maze (EPM) apparatus to evaluate anxiety and explorative behaviors. This task opposes the innate fear of rodents for open bright spaces to their desire to explore new environments. Security was provided by the closed arms, whereas the open arms offer exploratory values. Distance traveled of mice in different arms of the maze was measured by Top Scan 2.0. Total distance traveled was used as an indicator of motor function.

Novelty-suppressed feeding (Thatcher-Britton). After $24 \mathrm{~h}$ of food deprivation, time taken by the mice to reach food pellets in the center area of a rat open field $(120 \mathrm{~cm} \times 120 \mathrm{~cm})$ was measured on day 4 to evaluate anxious and explorative behaviors (maximum of $10 \mathrm{~min}$ ). Like EPM, this task approaches the conflict between the innate fear of rodents of the open bright center area of the arena versus their desire to feed. Security was provided by the walls of the arena.

MWM. In this task, mice were required to locate a fixed position hidden submerged platform $(10 \mathrm{~cm}$ diameter, $1 \mathrm{~cm}$ below water surface) in a water pool $(1.2 \mathrm{~m}$ diameter $)$ containing water $\left(24^{\circ} \mathrm{C}\right)$ that is rendered opaque by nontoxic white paint using distal visuospatial cues. Before the hidden platform training, a cued test, including three trials of $60 \mathrm{~s}$ in which the platform was visible, was conducted on day 0 of the second week of behavioral training to assess age-related visual deficits and motivation to escape from water. Swimming speed was used as a control of motor function, a parameter potentially altered by aging. On day 1 , mice were trained to find the hidden platform by pseudo-randomly placing the mice in a different position on each of the three 60-s-long trials per day for five consecutive days (days 1-5). The platform was positioned in the middle of the same quadrant in these trials. Animals were guided to the platform if it was not located within $60 \mathrm{~s}$. All the mice remained on the platform for $15 \mathrm{~s}$ before removal. At $60 \mathrm{~min}$ after the acquisition phase on day 5 , mice were given one probe trial of $60 \mathrm{~s}$ for which the platform was removed from the pool. The number of times the animal swam over the platform location was evaluated with a tracking system. After $2 \mathrm{~d}$ of rest, all animals were submitted to a reverse memory paradigm to assess reversal learning. Briefly, the platform was moved to the opposite quadrant while the position of visual cues stayed the same. Mice were then trained to find the new platform location for four consecutive days (three trials per day). A second probe test was conducted $60 \mathrm{~min}$ after the last acquisition trial on day 11. Finally, a third probe test was done $7 \mathrm{~d}$ later to reactivate and examine long-term memory processes. Animals were killed by decapitation $2-3 \mathrm{~h}$ after the last MWM probe test to allow IEG expression triggered by memory retrieval (day 18). After each trial, mice were immediately placed under a heat lamp to prevent hypothermia. To control for possible effects due to circadian cycles, all trials were performed at approximately the same time of the day between 10 and $15 \mathrm{~h}$. Data derived from the MWM task were recorded on a computer using a video tracking system.

Tissue preparation and biochemical analysis. The hippocampus and adjacent cortex from one half of the brain were dissected as previously reported (Lauterborn et al., 2000; Ménard and Quirion, 2012b), snap frozen, and stored at $-80^{\circ} \mathrm{C}$ for immunoblotting experiments. The other half-brain was fixed by immersion in $4 \%$ paraformaldehyde for $24 \mathrm{~h}$, cryoprotected in $30 \%$ sucrose for $48 \mathrm{~h}$, and stored at $-80^{\circ} \mathrm{C}$ for immunocytochemical experiments.

Immunoblotting. Tissue containing the hippocampus, entorhinal, perirhinal, and portions of adjacent neocortices were homogenized with a Polytron in $2 \mathrm{ml}$ of lysis buffer (50 mM Tris-acetate, $\mathrm{pH} 7.4,100 \mu \mathrm{M}$ EGTA, $5 \mu \mathrm{M}$ leupeptin, $200 \mu \mathrm{M}$ phenylmethylsulfonyl fluoride, and 1 $\mu \mathrm{g} / \mathrm{ml} \mathrm{N}$-tosyl-L-phenylalanine chloromethyl ketone, Sigma-Aldrich). Total protein concentrations were determined using bicinchoninic acid protein assay kit (Pierce). Western blot analysis was performed on aliquots of homogenates obtained from WT and $P d y n^{-1-}$ mouse brains. A total of $10 \mu \mathrm{g}$ of protein was loaded on $4-20 \%$ Tris-glycine gels (Invitrogen) and subjected to SDS-PAGE. Proteins were transferred onto 
Hybond-C nitrocellulose membranes (GE Healthcare). To block nonspecific sites, membranes were first incubated for $1 \mathrm{~h}$ at room temperature in PBS containing 2\% BSA. Membranes were next incubated with primary antibodies against Group $1 \mathrm{mGluR}$ (mGluR $1 \alpha$ and mGluR5, Millipore), Homer 1a (Santa Cruz Biotechnology), or Arc proteins (Cell Signaling) in PBS containing 2\% BSA. Bands corresponding to proteins were detected by peroxidase-conjugated secondary antibody (Santa Cruz Biotechnology) and revealed by Western Lightning Chemiluminescence Reagent Plus (PerkinElmer) on Kodak BioMax MS film (GE Healthcare). The same labeling procedure was used for negative controls with the primary antibody omitted. Actin level was used as a loading control. Immunoblots were placed on a Northern light illuminator, and computer-generated images were analyzed semiquantitatively by densitometry with a microcomputer imaging device (Imaging Research, MCID).

Immunocytochemistry. Coronal sections (20 $\mu \mathrm{m}$ ) of fixed brains (fixed with $4 \%$ paraformaldehyde and cryoprotected in $30 \%$ sucrose solution) at the level of dorsal hippocampus were washed in PBS, pH 7.4, for 5 min then immersed in methanol containing $0.3 \%$ $\mathrm{H}_{2} \mathrm{O}_{2}$ for $30 \mathrm{~min}$ at room temperature to quench endogenous peroxidases. After three washes of 5 min each in PBS, sections were preincubated with $10 \%$ normal goat serum (NGS) at room temperature for $1 \mathrm{~h}$, followed by incubation with polyclonal Pdyn (Millipore, dilution $1 / 1000$ ) or mGluR5 (dilution 1/5000) primary antibodies (in PBS with $1 \%$ NGS) overnight at $4^{\circ} \mathrm{C}$. Subsequently, sections were washed 3 times in PBS and incubated in biotinylated anti-guinea pig IgG for Pdyn or anti-rabbit for mGluR5 (1:1000, Vector Laboratories) in 1\% NGS for 30 min. After washing in PBS, sections were finally incubated with avidin biotinylated enzyme complex (ABC reagent, Vector Laboratories) diluted in PBS for $30 \mathrm{~min}$. The peroxidase reaction was performed with $0.02 \%$ hydrogen peroxide and $3,3^{\prime}$-diaminobenzidine tetrahydrochloride $(0.1 \%$ in $100 \mathrm{~mm}$ Tris- $\mathrm{HCl}$ buffer, $\mathrm{pH} 7.4)$. Sections were then washed in tap water, cleaned, and mounted on Superfrost Plus slides (Thermo Scientific). Immunohistochemical staining was visualized using bright-field microscopy at $4 \times$ and $20 \times$ magnification. Controls were prepared using the same labeling procedure with either primary or secondary antibody omitted.

Electrophysiology. Brains were rapidly removed from mice that were anesthetized by isoflurane, and coronal brain slices ( $350 \mu \mathrm{m}$ thick) were cut in hyperosmotic, ice-cold, and carbogenated slice cutting solution (in mm: 252 sucrose, $2.5 \mathrm{KCl}, 4 \mathrm{MgCl}_{2}, 0.1 \mathrm{CaCl}_{2}, 1.25 \mathrm{KH}_{2} \mathrm{PO}_{4}, 26 \mathrm{NaHCO}_{3}$ and 10 glucose, $\sim 360 \mathrm{mOsmol} / \mathrm{L}$ ) using a Vibratome. Freshly cut slices were incubated with carbogenated artificial CSF (aCSF in mM: $125 \mathrm{NaCl}$, $2.5 \mathrm{KCl}, 1 \mathrm{MgCl}_{2}, 2 \mathrm{CaCl}_{2}, 1.25 \mathrm{NaH}_{2} \mathrm{PO}_{4}, 26 \mathrm{NaHCO}_{3}$, and 25 glucose, $\sim 310 \mathrm{mOsmol} / \mathrm{L}$ ) at $32^{\circ} \mathrm{C}$ for $1 \mathrm{~h}$ and subsequently maintained at room temperature. Bicuculline methobromide ( $5 \mu \mathrm{M}$; Sigma-Aldrich) was used to block $\mathrm{GABA}_{\mathrm{A}}$ receptor-mediated inhibitory synaptic transmission in all recordings. Postsynaptic responses were evoked by stimulating the Schaffer collateral-commissural pathway (constant current pulses, $0.08 \mathrm{~ms}$ ) through a tungsten bipolar electrode (FHC) at $0.05 \mathrm{~Hz}$. Field EPSPs (fEPSPs) in hippocampal CA1 stratum radiatum were detected by aCSF-filled glass electrodes. Synaptic responses were amplified and digitized by Multiclamp 700B and Digidata 1400, respectively (Molecular Devices) and stored in a PC for offline analysis using Clampfit (Molecular Devices). All recordings were performed at room temperature. To induce mGluR-dependent LTD, dihydroxyphenylglycine (DHPG) (50 $\mu \mathrm{M}, 10 \mathrm{~min}$; Tocris Bioscience) was applied in aCSF. mGluR-LTD was measured at $60 \mathrm{~min}$ after the end of DHPG application.

Immunofluorescence. Coronal $20 \mu \mathrm{m}$ sections of fixed brains at the level of the dorsal hippocampus were washed in PBS, pH 7.4, for 5 min. Sections were permeabilized with $0.2 \%$ Tween 20 in PBS for 10 min at
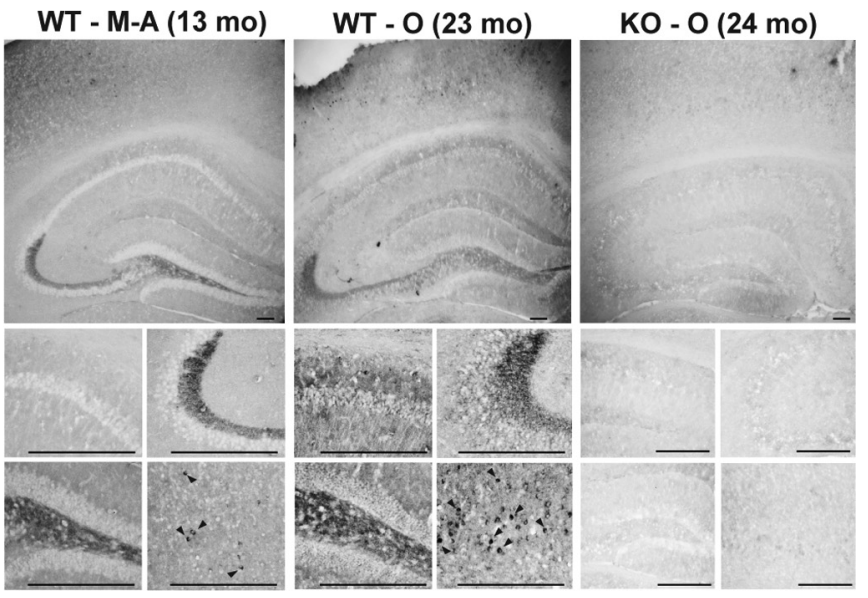

Figure 1. Expression of Pdyn increases during aging in WT mice brain. Pdyn immunostaining increases with age in the CA3 and and middle-aged (M-A) WT mice, old (0) animals show strong immunoreactivity in this area. Immunostaining is absent in djacent cortex. Scale bar, $200 \mu \mathrm{m}$. Arrowheads indicate Pdyn-positive cells.

room temperature and then processed for immunofluorescence labeling. In brief, sections were first incubated in 10\% NGS (or normal horse serum for Homer 1a) diluted in $0.1 \mathrm{M}$ PBS with $0.05 \%$ Tween 20 (PBST) and $1 \%$ BSA for $60 \mathrm{~min}$ at room temperature, followed by overnight incubation with primary antibodies (1:100 for Homer 1a and Arc and 1:500 for the neuronal marker microtubule-associated protein 2 [MAP2], Abcam) at $4^{\circ} \mathrm{C}$ in PBST containing $1 \%$ serum and $1 \%$ BSA. After 3 washes in PBS, sections were incubated with corresponding secondary antibodies (1:500, Invitrogen) conjugated with AlexaFluor-488 or AlexaFluor-568 in 1\% BSA in PBST for $2 \mathrm{~h}$ at room temperature in the dark. Sections were washed three times with PBS for 5 min each in the dark. Nuclei were stained with Hoechst solution $(2 \mu \mathrm{g} / \mathrm{ml}$, Invitrogen $)$ for $5 \mathrm{~min}$; subsequently, the sections were washed and coverslipped with Fluoromount-G (Southern Biotechnology). Pictures were taken at $40 \times$ magnification with an Axio Observer microscope with Apotome (Carl Zeiss).

Statistical analysis. All data are presented as mean \pm SEM. Data of protein levels, MWM parameters, NOR interaction time, distance traveled, and time to reach food were analyzed by two-way ANOVA, followed by Bonferroni post hoc analysis (GraphPad Prism software). Percentage depression of fEPSP during LTD was analyzed using twotailed Student's $t$ test. IEG protein levels and behavioral data correlations were evaluated with a two-tailed Pearson's test. Significance level was set at $p<0.05$.

\section{Results}

\section{Group 1 metabotropic glutamate receptor expression and} function increases with age in $P d y n^{-/-}$mice

We first compared Pdyn expression in young (Y, 7 months old), middle-aged (M-A, 13 months old), and old (O, 23 months old) C57BL/6 WT mice. Consistent with previously published findings (Schwarzer, 2009), Pdyn immunostaining was enriched in the CA3 and dentate gyrus of the adult hippocampus (Fig. 1). Interestingly, positive staining was observed in the CA1 region only for old WT mice. Pdyn expression increased with age in both the hippocampus and adjacent cortex. No Pdyn staining was observed in old $P d y n^{-1-}$ mice (KO-O, 24 months old).

We next evaluated Group $1 \mathrm{mGluR}$ levels in the hippocampal formation of young, middle-aged, and old WT and $P d y n^{-1-}$ mice. mGluR1 $\alpha$ (Fig. 2A; genotype effect $F_{(1,30)}=4.73, p=0.0376,93.8 \pm$ $12.0 \%$ for WT vs $154.6 \pm 26.7 \%$ for $\left.P d y n^{-l-}, n=6\right)$ and mGluR5 protein levels (Fig. $2 B$; genotype effect $F_{(1,30)}=6.78, p=0.0142$, $121.1 \pm 13.5 \%$ for WT vs $210.3 \pm 24.6 \%$ for $P d y n^{-1-}, n=6$ ) were 

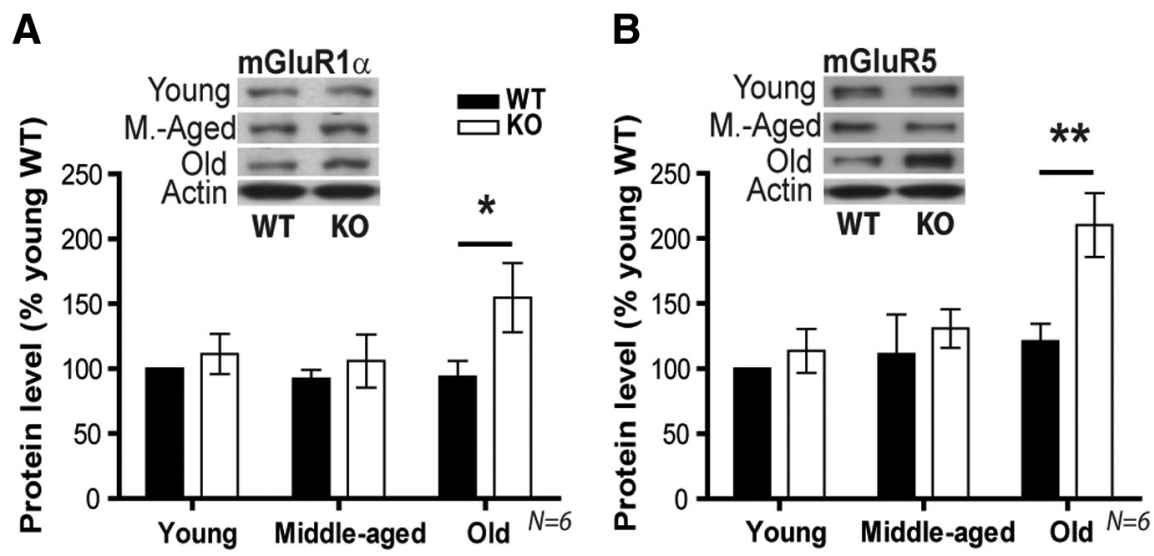

C

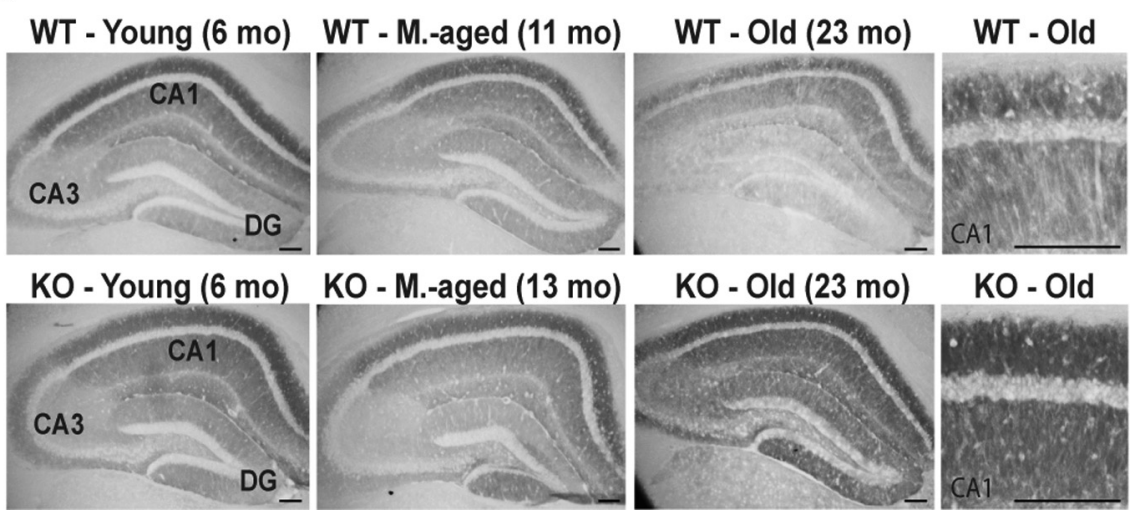

Figure 2. Group $1 \mathrm{mGluR}$ expression is specifically increased in old $P d y n^{-1-}$ mice hippocampus. $\boldsymbol{A}$, Hippocampal mGluR1 $\alpha$ protein level was significantly increased in old $P d y n^{-1-}$ mice compared with WT mice. $\boldsymbol{B}$, Hippocampal mGlu5 receptor level was significantly increased in old $P d y n^{-1-}$ mice compared with WT mice, particularly in the CA1 region as shown by immunohistochemistry (C). C, Western blot values represent mean \pm SEM of five separate experiments $(n=6$ for each age group and genotype), and data are expressed as percentage of control (6-month WT mice). Scale bar, $200 \mu \mathrm{m}$. ${ }^{*} p<0.05$ (two-way ANOVA with Bonferroni post test). ${ }^{* *} p<0.01$ (two-way ANOVA with Bonferroni post test).

significantly increased only in old $P d y n^{-1-}$ mice hippocampus and adjacent cortex. mGluR5 immunoreactivity revealed intensely stained pyramidal neurons in the hippocampal CA1 region (Fig. $2 C)$. Specificity of the antibody was controlled with mGluR5 peptide preadsorption (data not shown). Although immunostaining slightly decreased during aging for WT mice, higher immunoreactivity was observed in the CA1 region of old $P d y n^{-1-}$ (Fig. $2 C$ ).

To test whether Group $1 \mathrm{mGluR}$ function is affected in $P d y n^{-1-}$ mice, we studied the effect of pharmacological activation of Group 1 mGluRs with a specific agonist DHPG on synaptic function. DHPG has been shown to induce LTD of glutamatergic transmission (Palmer et al., 1997). We examined changes in the slope of fEPSPs in the hippocampal CA1 region of both old WT and $P d y n^{-1-}$ mice after DHPG application ( $50 \mu \mathrm{M}, 10 \mathrm{~min}$; Fig. $3 A)$. We found that the percentage depression at $60 \mathrm{~min}$ after DHPG application in old $P d y n^{-1-}$ slices was significantly higher than age-matched WT controls (Fig. $3 B ;-30.4 \pm 5.7 \%$ in $P d y n^{-1-}$ vs $-4.2 \pm 6.4 \%$ in WT, unpaired two-tailed $t$ test $p=0.0123, n=6$ slices/genotype with 3-4 mice per genotype). To examine whether the impact of $P d y n$ knockdown on mGluR function occurs in aged mice only, we performed LTD recordings in young WT and $P d y n^{-1-}$ mice (8-9 months old) but found no differences (Fig. $3 C, D$ ). Knockdown of $P d y n$ therefore increases Group $1 \mathrm{mGluR}$ expression and function in the aged hippocampus.
Spatial memory is intact in $P d y n^{-1-}$ mice despite aging

Synaptic plasticity is crucial to maintain cognitive abilities, and LTD induced by Group 1 mGluR activation has been linked to memory in the aging brain (Lee et al., 2005). We predicted that the maintenance of mGluR expression and LTD would protect old mice from displaying cognitive impairment. We trained 6-, $10-$ 14-, and 18-25-month-old WT and $P d y n^{-1-}$ mice in a hippocampal-dependent MWM task to assess their spatial memory. No differences were observed between the groups in the visible platform trials that assess swimming ability, visual function, and motivation (Fig. $4 A$ ). In the hidden platform trials, old WT mice became memory-impaired and exhibited longer escape latencies than younger mice (Fig. 4B; age effect: one-way ANOVA, $F_{(2,46)}=9.35, p=0.0004$, escape latency on day 5: young: $18.2 \pm 2.2 \mathrm{~s}$; middleaged: $24.3 \pm 3.6 \mathrm{~s}$; old: $32.4 \pm 2.2 \mathrm{~s}, n=$ 15-16). Genetic deletion of $P d y n$ prevented this deficit with latencies to escape to the platform comparable to young and middle-aged animals (age effect: one-way ANOVA, $F_{(2,33)}=0.888, p=0.421$, escape latency on day 5: young: $12.6 \pm 1.4 \mathrm{~s}$; middle-aged: $17.7 \pm 2.4$ s; old: $19.5 \pm$ $3.8 \mathrm{~s}, n=10-18)$. Average escape latencies of old $P d y n^{-1-}$ mice were significantly lower than WT mice on hidden platform training days 3, 4, and 5, and two-way ANOVA analysis revealed significant difference in learning acquisition for $P d y n^{-1-}$ compared with WT $\left(F_{(1,96)}=\right.$ $13.4, p=0.0012)$.

Inhibitory learning and reversal memory are highly dependent on hippocampal LTD (Dong et al., 2013). mGluR5 knockout mice perform poorly in reversal learning (Xu et al., 2009), suggesting that the intact mGluR-LTD in aged $P d y n^{-1-}$ animals can rescue reversal learning of these mice. We found that old WT mice were unable to learn the new platform position in a reversal learning paradigm (Fig. $4 C$; time effect: one-way ANOVA, $F_{(3.60)}=$ $1.318, p=0.277$, escape latency on day 8: $43.3 \pm 2.7 \mathrm{~s}$, day 9: $38.8 \pm 3.9 \mathrm{~s}$; day $10: 35.5 \pm 3.2 \mathrm{~s}$; day $11: 35.0 \pm 3.5 \mathrm{~s}, n=16)$. On the other hand, old $P d y n^{-1-}$ exhibited successful reversal learning (time effect: one-way ANOVA, $F_{(3,36)}=2.96, p=0.0459$, escape latency on day $8: 25.8 \pm 4.2 \mathrm{~s}$, day $9: 18.8 \pm 3.0 \mathrm{~s}$, day 10 : $17.4 \pm 1.6 \mathrm{~s}$, day $11: 15.7 \pm 2.7 \mathrm{~s}, n=10)$. Moreover, the average escape latency of old $P d y n^{-1-}$ mice on day 11 was similar to young and middle-aged $P d y n^{-1-}$ mice (age effect: one-way ANOVA, $F_{(2,27)}=1.20, p=0.317$, young: $10.8 \pm 2.2 \mathrm{~s}$; middleaged: $15.8 \pm 3.2 \mathrm{~s}$; old: $15.7 \pm 2.7 \mathrm{~s}, n=10-18)$, suggesting intact memory processes. Reversal learning curves were significantly different between the old mice groups (genotype effect: two-way ANOVA, $\left.F_{(1,72)}=26.2, p<0.0001\right)$.

Unimpaired spatial memory in old $P d y n^{-1-}$ mice was also suggested by probe trials (Fig. $5 A$ ). Probe trials were performed 60 min after the last hidden platform training on day 5 of learning and day 11 of reverse acquisition tasks. The number of platform 
A
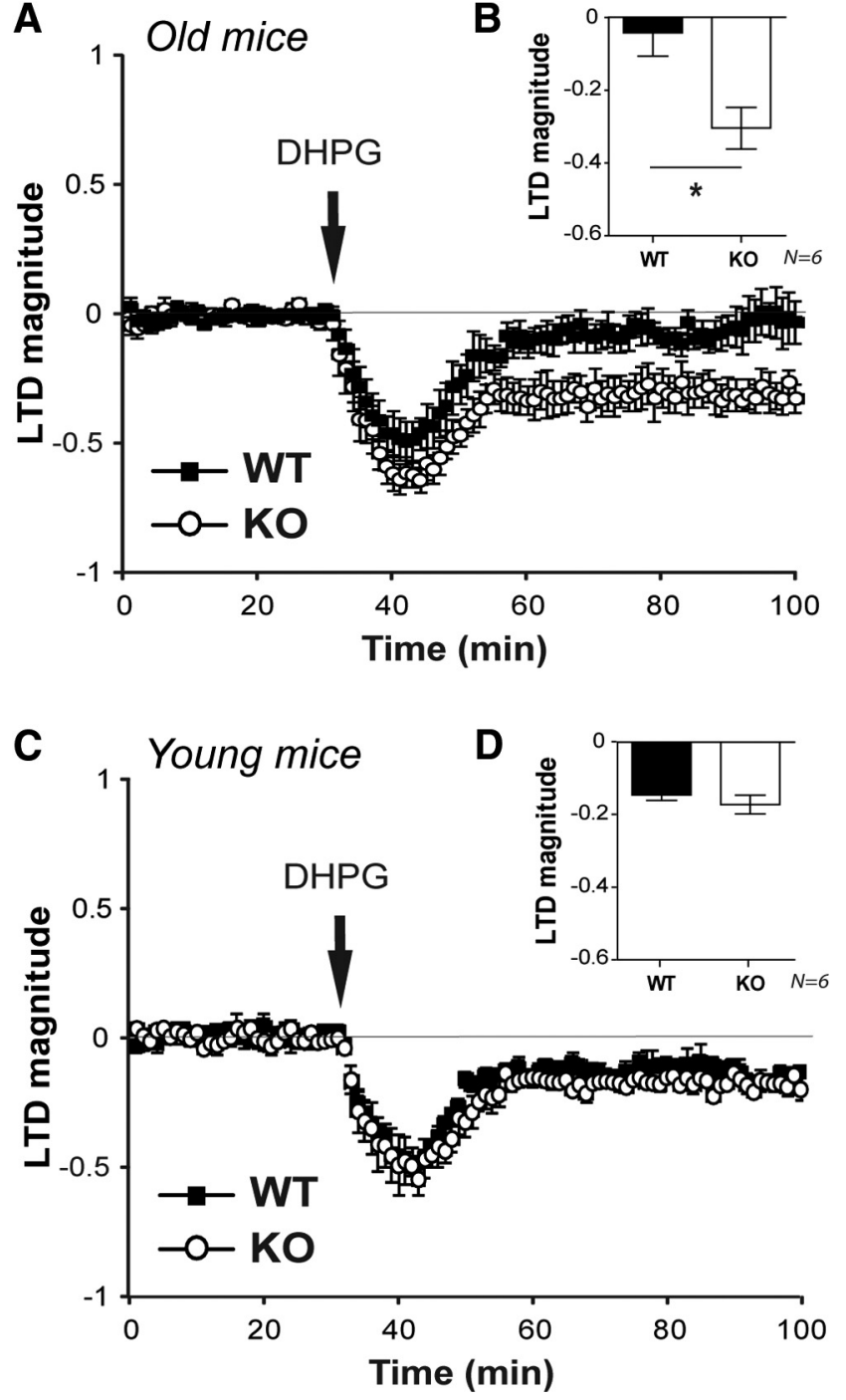

Figure 3. Group $1 \mathrm{mGluR}$ function is increased in old $P d y n^{-1-}$ mice hippocampus. $A$, After 30 min of baseline recording, DHPG, a specific Group $1 \mathrm{mGluR}$ agonist, was applied for $10 \mathrm{~min}$ to slices from either old WT or Pdyn ${ }^{-/-}$mice. Only Pdyn ${ }^{-1-}$ mice expressed significant LTD in the hippocampal CA1 region at 60 min after DHPG application. $B$, Percentage depression of fEPSP slope at 60 min after DHPG application in old $P d y n^{-1-}$ slices was significantly higher than WT slices. C, mGluR-LTD function is similar in young WT and $P d y n^{-1-}$ mice. D, Percentage depression of fEPSP slope at 60 min after DHPG application was not significantly different between young WT and Pdyn ${ }^{-1-}$ mice. Recordings represent mean \pm SEM of six separate experiments ( $n=6$ slices from 3 or 4 mice per genotype). ${ }^{*} p<0.05$ (unpaired two-tailed $t$ test for LTD magnitude).

crossings decreased with age for the WT mice after regular learning (age effect: one-way ANOVA, $F_{(2,46)}=5.21, p=0.0092$, day 5: young: $3.9 \pm 0.5$; middle-aged: $3.4 \pm 0.5$; old: $1.9 \pm 0.3)$ and reversal learning probe tests (age effect: one-way ANOVA, $F_{(2.46)}=$ $4.56, p=0.0156$, day 11 : young: $4.2 \pm 0.6$; middle-aged: $3.3 \pm$ 0.6 ; old: $1.9 \pm 0.4, n=15-16$ ). Conversely, we observed no age differences in $\mathrm{Pdyn}{ }^{-1-}$ mice platform crossings during probe tests after regular learning (age effect: one-way ANOVA, $F_{(2,28)}=$ $3.28, p=0.0526$, day 5: young: $6.2 \pm 0.8$; middle-aged: $3.2 \pm 0.8$; old: $4.1 \pm 0.9$ ) and reversal learning tasks (age effect: one-way ANOVA, $F_{(2,28)}=0.735, p=0.489$, day 11: young: $5.5 \pm 0.5$; middle-aged: $4.0 \pm 0.9$; old: $4.6 \pm 0.8, n=10-18)$. Old Pdyn ${ }^{-1-}$ mice crossed the hidden platform positions significantly more times than old WT mice in both probe tests (genotype effect: two-way ANOVA, $\left.F_{(1,24)}=10.9, p=0.003, n=10-18\right)$. Old
$P d y n^{-1-}$ mice swimming speed was not significantly different from WT mice during probe tests (Fig. $5 B$; aging and genotype effect: two-way ANOVA, $F_{(1,24)}=3.18, p=0.0872, n=10-16$ ). Together, these results support our hypothesis that the increase in Group $1 \mathrm{mGluR}$ expression and function in old $\mathrm{Pdyn}^{-/-}$mice associates with improved spatial learning in these animals.

Spatial memory is rescued in old WT mice by mGluR5positive modulator CDPPB or KOR antagonist norBNI

If the impact of aging on spatial memory performance is related to an increase and a decrease in Pdyn and mGluR5 function, respectively, we predicted that old WT mice spatial memory deficits could be improved by either enhancing Group 1 mGluR function or blocking KOR activation. To test this hypothesis, old WT mice were injected with DMSO (vehicle), mGluR5 allosteric modulator CDPPB or norBNI, an antagonist of KOR, $20 \mathrm{~min}$ before the start of training on each training day and spatial memory was assessed with the MWM task. Old WT and $P d y n^{-1-}$ mice were first trained to find a visible platform. Neither genotype (Fig. 6A) nor pharmacological treatment (Fig. 6B) affected motivation to escape water, visual function, or motor function. Treatments with CDPPB or norBNI significantly improved old WT mice acquisition of the task in the first 5 training days (Fig. $6 C$, two-way ANOVA compared with untreated old WT: $F_{(1,80)}=$ $7.14, p=0.0146$ for CDPPB, Bonferroni post tests $<0.05$ on days 4 and $5 ; F_{(1,88)}=19.65, p=0.0002$ for norBNI, Bonferroni post tests $<0.05$ on days 2,3 , and 4 and $F_{(1,76)}=0.16, p=0.694$ for vehicle, $n=5-16)$. Similar results were obtained for acquisition of reversal learning with shorter latencies for old WT mice treated with $\mathrm{CDPPB}$ or norBNI compared with vehicle or untreated mice (Fig. 6D; two-way ANOVA compared with untreated old WT: CDPPB, $F_{(1,60)}=2.23, p=0.151$, Bonferroni post tests $<0.05$ on day 11; norBNI: $F_{(1,66)}=13.7, p=0.0013$, Bonferroni post tests $<0.05$ on days 9,10 , and 11; vehicle: $F_{(1,57)}=0.20, p=$ $0.663, n=5-16)$. Finally, CDPPB and norBNI enhanced old WT mice platform crossings for both normal learning and reversal learning probe tests compared with untreated mice (Fig. 6E; two-way ANOVA compared with untreated old WT, CDPPB: $F_{(1,20)}=21.73$, $p=0.0002$; norBNI: $F_{(1,22)}=14.13, p=0.0011$; vehicle: $F_{(1,19)}=$ $0.67, p=0.4242, n=5-16)$.

Protective effect of $\mathrm{Pdyn}^{-1-}$ on spatial memory in old mice is abolished by the mGluR5 inhibitor MPEP

If the protective effect of knocking down $P d y n$ on spatial memory formation in old $P d y n^{-1-}$ mice is related to the enhancement of mGluR5 function, we expected that intact spatial memory of these mice will be affected by blocking mGluR5. To test that, we injected old $P d y n^{-1-}$ mice with the mGluR5 antagonist MPEP or DMSO (vehicle) 20 min before the start of training on each training day. As expected, MPEP impaired the acquisition of the MWM task of old $P d y n^{-1-}$ mice by increasing the latencies for finding the hidden platform on training days 4 and 5 (Fig. 6C; two-way ANOVA compared with untreated old $P d y n^{-1-}$ mice: $F_{(1,60)}=3.11, p=0.0983$ for MPEP, Bonferroni post tests $<0.05$ on days 4 and 5 and $F_{(1,52)}=0.01, p=0.941$ for vehicle, $n=$ 5-10). In addition, MPEP impaired reversal MWM learning of old $P d y n^{-1-}$ mice on training days 8,9 , and 10 (Fig. 6D; two-way ANOVA compared with untreated old $P d y n^{-1-}$ mice: MPEP $F_{(1,45)}=11.37, p=0.0042$, Bonferroni post tests $<0.05$ on days 8,9 , and 10; vehicle: $\left.F_{(1,39)}=0.47, p=0.5059, n=5-10\right)$. Finally, MPEP-treated old $P d y n^{-1-}$ mice displayed probe trials performances that were significantly poorer than untreated and vehicle-treated old $P d y n^{-1-}$ mice (Fig. 6E; two-way ANOVA 


\section{A Cued test (visible platform)}
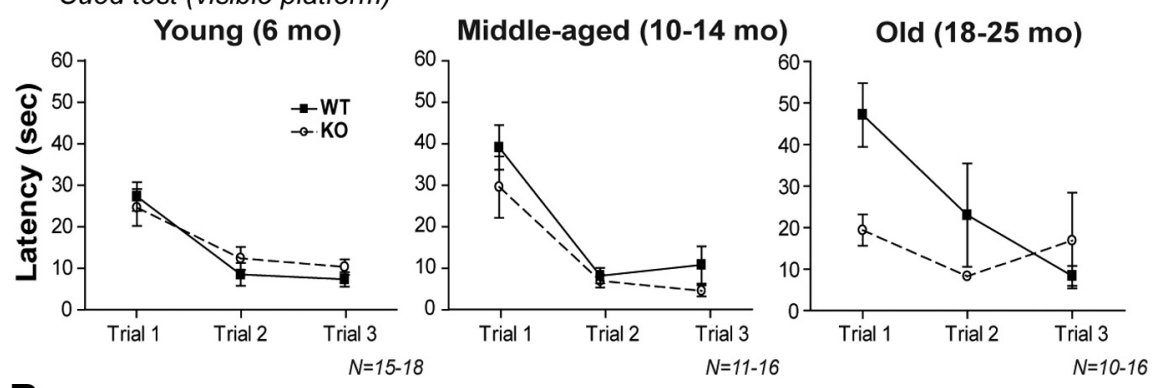

\section{B}
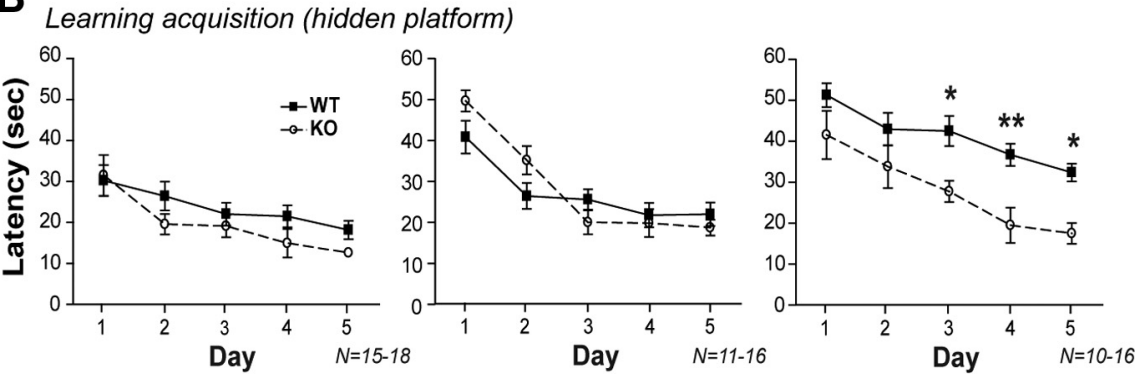

C

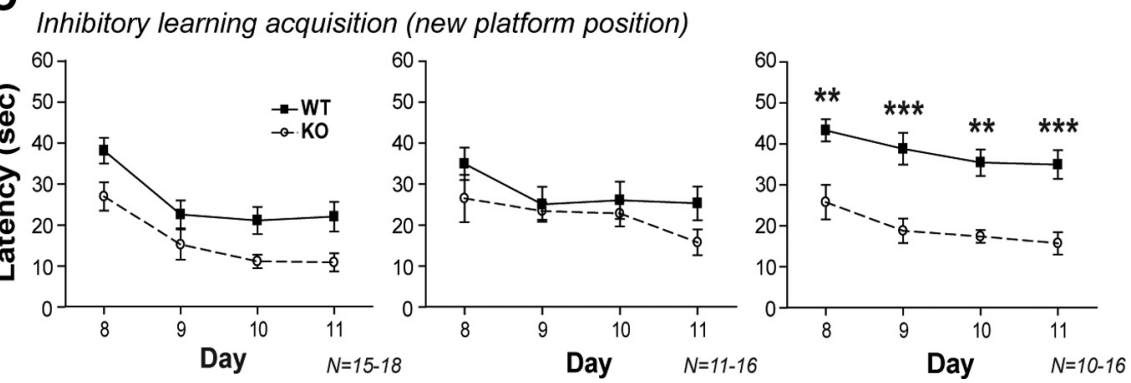

Figure 4. No aging-related spatial memory impairment in old $P d y n^{-1-}$ mice. $A$, All mice learned to swim to the visible platform to escape water after three trials of 60 s regardless of age and genotype (delay of 30 min between each trial). A flag was positioned on the platform as a visual clue. $\boldsymbol{B}$, Hidden platform MWM learning acquisition curves of the young (6 months), middle-aged (10-14 months), and old (18-25 months) WT versus $P d y n^{-1-}$ mice ( 3 trials/d). $\boldsymbol{C}$, After 2 d of rest, the platform was moved to the opposite quadrant to assess inhibitory learning acquisition ( 3 trials/d). Data represent mean \pm SEM for all animals of each group ( $n=10-18$ for each group and genotype) trained in two different cohorts. ${ }^{*} p<0.05$ (two-way ANOVA followed by Bonferroni post test). ${ }^{* *} p<0.01$ (two-way ANOVA followed by Bonferroni post test). ${ }^{* *} p<0.001$ (two-way ANOVA followed by Bonferroni post test).

compared with untreated old $P d y n^{-1-}$ mice: $F_{(1,15)}=4.81, p=$ 0.0444 for MPEP and $F_{(1,13)}=0.08, p=0.7804$ for vehicle, $n=$ $5-10)$.

Group $1 \mathrm{mGluR}$-related immediate early gene Homer $1 a$ and Arc expression is high in old $P d y n^{-/-}$mice and correlated with MWM performances

Formation and consolidation of memories involve the expression of various IEGs, including Homer $1 a$ and Arc (Ménard and Quirion, 2012b). If the increase of mGluR expression and function in $P d y n^{-1-}$ mice is responsible for rescuing age-related cognitive deficits in these mice, we expect that the enhanced cognitive performance of $P d y n^{-1-}$ mice associates with increases in the expression of downstream mGluR signals, such as Homer 1a and Activity-regulated cytoskeleton associated protein (Arc also known as Arg 3.1). Homer la protein level increased with age in $P d y n^{-1-}$ mice after MWM training (Fig. 7A; young: $93.7 \pm$ $12.5 \%$, middle-aged: $115.7 \pm 15.6 \%$, old: $154.5 \pm 18.9 \%, n=6$ ), whereas it remained stable in WT mice (young: $100 \%$, middleaged: $115.2 \pm 20.1 \%$, old: $100.9 \pm 8.5 \%, n=6$ ). The effect of age and genotype is significant between the old groups. Homer la expression is positively correlated with old mice MWM probe test performance (average of regular and reversal learning platform crossings) (Fig. 7B; Pearson correlation: $p=0.0041)$. More Homer 1apositive cells were observed in the CA1 hippocampal region of old $P d y n^{-/-}$mice compared with WT mice at the same age (Fig. 7C).

In line with the age-related cognitive decline, Arc protein level decreased gradually with aging in WT mice hippocampal formation (Fig. 7D; age effect: one-way ANOVA, $F_{(2,15)}=7.159, p=0.0066$, young: $100 \%$, middle-aged: $85.4 \pm 7.4 \%$; old: $73.29 \pm 6.2 \%, n=6$ ). Conversely, Arc expression was maintained in old $P d y n^{-1-}$ mice (age effect: one-way ANOVA, $F_{(2,15)}=0.9815, p=0.3976$, young: $89.2 \pm 9.2 \%$; middle-aged: $109.5 \pm 13.5 \%$; old: $105.4 \pm 4.1 \%, n=6$ ). Again, the effect of genotype on Arc expression was significant between old mice groups. Similar to Homer 1a, Arc expression was positively correlated with old mice MWM probe test performance (Fig. $7 E$; Pearson correlation: $p=0.0014)$. The number of Arc-positive-cells was higher in old Pdyn ${ }^{-1-}$ CA1 hippocampal area compared with WT (Fig. 7F). The correlation between the levels of mGluR downstream signals and cognitive performance of $P d y n^{-1-}$ mice suggests an important role of maintaining mGluR expression and function for the intact spatial learning of these mice.

\section{Recognition memory is intact in old Pdyn ${ }^{-1-}$ mice}

To find out whether age-related impairments of nonspatial memory (Rowe et al., 1998; Burke et al., 2011) are also protected in old $P d y n^{-1-}$ mice, we compared the performance of WT and $P d y n^{-1-}$ mice in both a long-term recognition memory task and a novel object recognition task. Mice were first exposed to two identical objects for $5 \mathrm{~min}$. Recognition memory was tested by comparing time of interaction with a new versus familiar object after $5 \mathrm{~min}, 60 \mathrm{~min}$, and $24 \mathrm{~h}$ delays. Old WT mice displayed memory deficits by spending close to $50 \%$ time (chance level) with the novel object (Fig. 8A). On the other hand, old $P d y n^{-1-}$ mice spent consistently more time with the novel object than old WT mice (ratio for $P d y n^{-1-}$ vs WT for 5 min: $65.3 \pm 3.9 \%$ vs $49.4 \pm 6.7 \%$; $60 \mathrm{~min}: 75.2 \pm 3.9 \%$ vs $51.2 \pm 5.9 \% ; 24 \mathrm{~h}: 62.6 \pm 3.0 \%$ vs $47.4 \pm 6.5 \%, n=8-17$ ), suggesting intact recognition memory. Genotype effect was significant between old WT and $P d y n^{-1-}$ mice (two-way ANOVA, $\left.F_{(1,69)}=13.17, p=0.0014\right)$ but not between young and middle-aged mice.

Apart from cognitive deficits, aging associates also with altered emotional behaviors, such as increased anxiety (Lenze et al., 2001). The implicated role of dynorphin in anxiety-related behaviors (Schwarzer, 2009) suggests that $P d y n^{-1-}$ could protect aged mice from increased anxiety. Indeed, in the novel object 
recognition task, $P d y n^{-/-}$mice exhibit higher exploratory activity. $P d y n^{-1-}$ mice consistently traveled a longer distance in 5 min than WT mice of the same age (Fig. $8 B ; P d y n^{-1-}$ vs WT: young: $8.5 \pm 2.2 \mathrm{~m}$ vs $4.2 \pm 0.4 \mathrm{~m}$; middle-aged: $10.4 \pm 1.6 \mathrm{~m}$ vs $6.8 \pm 1.0 \mathrm{~m}$; old: $5.8 \pm 0.6 \mathrm{~m}$ vs $3.6 \pm$ $0.4 \mathrm{~m}, n=7-17)$. Representative paths are shown in Figure $8 C$.

To find out whether age-related changes in recognition memory and exploratory behaviors in old WT mice are related to the enhanced $P d y n$ and reduced mGluR5 expression, we evaluated the impact of CDPPB and norBNI treatments on old WT mice recognition memory and found that these pharmacological manipulations improved old WT mice performances in these tasks (Fig. 8D; two-way ANOVA compared with untreated old $\mathrm{WT}: F_{(1,42)}=4.85, p=0.0448$ for CDPPB, Bonferroni post tests $<0.05$ at $5 \mathrm{~min}$ delay and for average values; $F_{(1,42)}=9.46$, $p=0.0082$ for norBNI, Bonferroni post tests $<0.05$ at $24 \mathrm{~h}$ delay and for average values and $F_{(1,33)}=1.65, p=0.2253$ for vehicle, $n=5-8)$. We also examined whether the protective effects of $P d y n^{-1-}$ on old mice performance in these recognition memory tasks were related to the enhancement of mGluR5 function by studying the impact of MPEP on recognition memory formation in old $P d y n^{-1-}$. Surprisingly, we observed no effect of MPEP on old $P d y n^{-1-}$ mice performances (Fig. 8D; two-way ANOVA and comparison with untreated old $P d y n^{-1-}$ mice: MPEP, $F_{(1,69)}=3.85, p=0.0620$; vehicle: $\left.F_{(1,60)}=0.02, p=0.8827, n=5-17\right)$. Finally, these drugs did not significantly alter locomotion or exploratory activity (Fig. $8 E$; WT: $3.6 \pm 0.4 \mathrm{~m}$ vs $P d y n^{-1-}: 5.8 \pm 0.6 \mathrm{~m}$ vs norBNI: $5.3 \pm$ $0.2 \mathrm{~m}, n=5-17)$.

\section{Anxiety levels remain low in $P d y n^{-/-}$mice despite aging}

Higher locomotor and exploration activities observed in $P d y n^{-1-}$ mice compared with WT (genotype effect: two-way ANOVA, $\left.F_{(1,64)}=11.70, p=0.0011\right)$ suggest that anxiety-related behaviors could be reduced in these mice. We thus investigated further the anxiety state of mice using the EPM task. Mice have to overcome the fear of bright open space to explore a novel environment while security was provided by the closed arms. No difference was observed for distance traveled in the EPM open arms for young animals (Fig. 9A). However, aging affected anxiety-related behaviors as middle-aged and old WT mice traveled a shorter distance in the EPM open arms than young mice (age effect: one-way ANOVA, $F_{(2,27)}=4.30, p=0.0274$, young: $116.4 \pm 53.8 \mathrm{~mm}$; middle-aged: $29.8 \pm 12.9 \mathrm{~mm}$; old: $44.1 \pm 15.8$ $\mathrm{mm}, n=8-15)$. In contrast, $P d y n^{-1-}$ mice at all ages traveled a similar distance in the open arms (age effect: one-way ANOVA, $F_{(2,28)}=0.0952, p=0.910$, young: $221.6 \pm 77.2 \mathrm{~mm}$; middleaged: $179.6 \pm 50.2 \mathrm{~mm}$; old: $248.5 \pm 107.2 \mathrm{~mm}, n=7-15)$, indicating no effect of aging on anxiety in these mice. Aging and the genotype effect (two-way ANOVA, $F_{(1,61)}=5.80, p=0.0191$ ) were significant for both middle-aged and old mice groups. Locomotion activity was higher for $P d y n^{-/-}$young and old groups (Fig. 9B) (genotype effect: two-way ANOVA, $F_{(1,63)}=11.08, p=$ $0.0015, n=7-15)$. Representative paths are shown on Figure $9 C$.
Next, we tested the impact of mGluR5-related drugs on EPM performances in old WT and $P d y n^{-1-}$ mice. Positive modulation of mGluR5 had no impact on old WT mice behavior, whereas treatment with MPEP significantly reduced distance traveled in the open arms for $P d y n^{-1-}$ mice (Fig. 9D; MPEP: $60.6 \pm 13.4 \mathrm{~mm}$; vehicle: $218.2 \pm 91.9 \mathrm{~mm} ; P d y n^{-1-}$ : $248.5 \pm 107.2 \mathrm{~mm}, n=5-15)$. To find out whether the improved EPM performances in old $P d y n^{-1-}$ mice are related to a reduction of dynorphin receptor function, we examined the impact of norBNI on the EPM performances of old WT mice and found that norBNI enhanced locomotion and exploratory activity of old WT mice compared with untreated controls (Fig. 9E; WT: $3.4 \pm 0.2 \mathrm{~m}$ vs $P d y n^{-1-}: 5.3 \pm 0.6 \mathrm{~m}$ vs norBNI: $5.1 \pm 0.3 \mathrm{~m}, n=5-15)$, suggesting that blocking activation of these receptors decreases age-related anxious behaviors.

Finally, we examined the anxiety state of $P d y n^{-1-}$ and WT mice using the novelty-suppressed feeding (Thatcher-Britton) task. In this test, we measured the time mice use to reach the food in the middle of a light exposed open field arena. As expected, time to reach food increased with age in WT mice (Fig. $10 A$; one-way ANOVA, $F_{(2,33)}=4.90, p=0.0137$, young: $282.1 \pm 37.4$ s; middle-aged: $361.2 \pm 50.8$ s; old: $494.0 \pm$ $40.8 \mathrm{~s}, n=8-15)$. Aging had a similar effect on $P d y n^{-1-}$ mice (one-way ANOVA, $F_{(2,30)}=6.328, p=0.0051$, young: $144.4 \pm$ $31.8 \mathrm{~s}$; middle-aged: $266.6 \pm 63.6 \mathrm{~s}$; old: $378.4 \pm 51.0 \mathrm{~s}, n=$ 7-15). Nonetheless, the average food-seeking time is consistently lower for $P d y n^{-1-}$ compared with WT at all ages (genotype effect: two-way ANOVA, $\left.F_{(1.63)}=8.30, p=0.0054\right)$. Positive modulation of mGluR5 by CDPPB significantly reduced the time to reach food of old WT mice compared with untreated controls (Fig. 10B; CDPPB: $214.5 \pm 41.0 \mathrm{~s}$; WT: $494.0 \pm 40.8 \mathrm{~s}, n=5-15)$. Together, our results suggest that high Pdyn and low mGluR5 expression in the aged brain could increase anxiety-related behaviors and impair memory formation. 


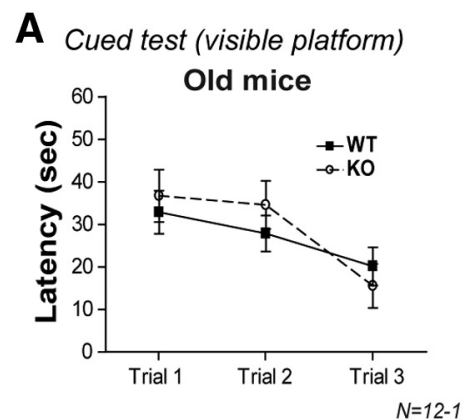

C Learning acquisition (hidden platform)

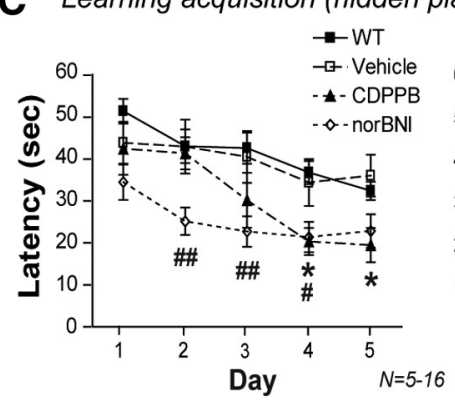

D Inhibitory learning acquisition (new platform position)

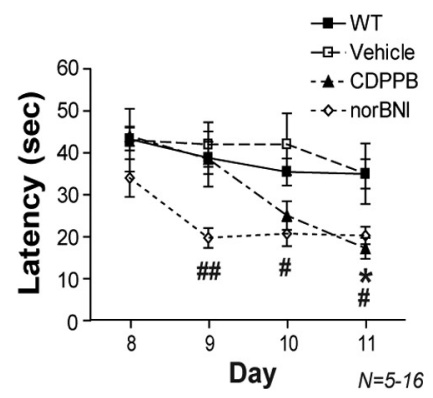

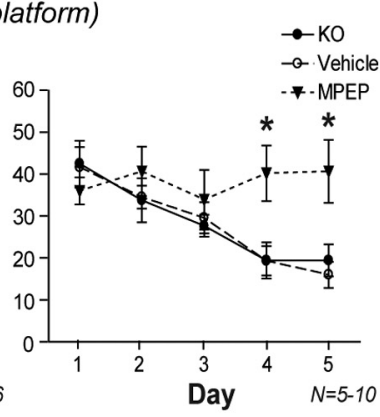

B

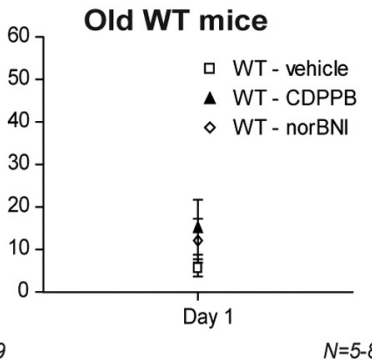

$N=5-8$
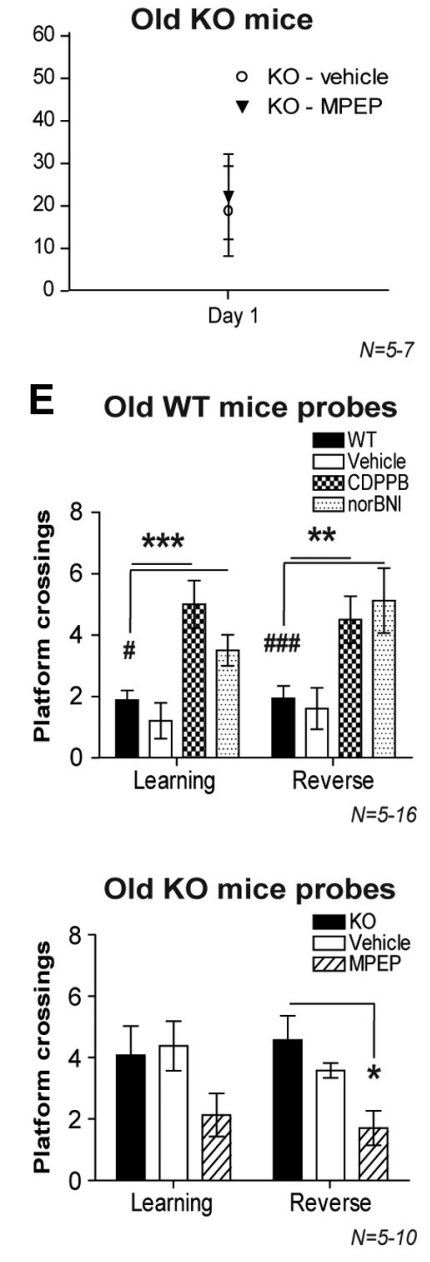

Figure 6. Spatial memory is rescued in old WT mice by treatments with mGluR5-positive allosteric modulator CDPPB or $\kappa$-opioid receptor antagonist norBNI, whereas MPEP, a selective antagonist of mGluR5, impaired old $P d y n^{-1-}$ mice cognition. $\boldsymbol{A}$, All old mice (18-25 months) learned to swim to the visible platform to escape water after three trials of 60 s on day $0 . \boldsymbol{B}$, Mice were injected intraperitoneally 20 min before testing on day 1 with CDPPB, norBNI, or DMSO (vehicle) for old WT mice group and MPEP or DMSO (vehicle) for old Pdyn ${ }^{-1-}$ group. Drugs did not affect mice cued test performance. C, Learning acquisition of the hidden platform position after pharmacological treatments compared with untreated old WT and Pdyn ${ }^{-1-}$ mice ( 3 trials/d). D, 0n day 8 , the platform was moved to the opposite quadrant to assess inhibitory learning acquisition ( 3 trials/d). $\boldsymbol{E}$, Average platform crossings during probe tests conducted $1 \mathrm{~h}$ after the last training trial of normal and reversal spatial learning. Data represent mean \pm SEM for all animals of each group $(n=5 /$ genotype for vehicle, $n=8 /$ drug for injected mice, and $n=10-16 /$ genotype for control untreated mice). For CDPPB or MPEP treatment: ${ }^{*} p<0.05$ (two-way ANOVA followed by Bonferroni post tests performed between treated groups and untreated controls); ${ }^{* *} p<0.01$ (two-way ANOVA followed by Bonferroni post tests performed between treated groups and untreated controls); ${ }^{* * *} p<0.001$ (two-way ANOVA followed by Bonferroni post tests performed between treated groups and untreated controls). After injection with norBNI: \#p $<0.05$ (two-way ANOVA followed by Bonferroni post tests performed between treated groups and untreated controls); \#\# $<0.01$ (two-way ANOVA followed by Bonferroni post tests performed between treated groups and untreated controls); \#\# $<0.001$ (two-way ANOVA followed by Bonferroni post tests performed between treated groups and untreated controls).

\section{Discussion}

In the present study, we found that knocking down Pdyn gene expression ameliorated several cognitive, synaptic, and molecular changes that are associated with aging. First, knocking down $P d y n$ rescued aged mice from deficits of spatial and recognition memory. In addition, the aging-associated increase in anxietyrelated behaviors and decrease in exploratory activity are suppressed in $P d y n^{-1-}$ mice. At the synaptic level, we found that knocking down Pdyn increased Group 1 mGluR expression and, importantly, rescued the weakening of hippocampal mGluRLTD in aging. In line with these results, blocking mGluR5 activity impaired old $P \mathrm{dyn}^{-1-}$ mice spatial memory and enhanced anxious behaviors in the EPM task. In contrast, blocking KOR function or enhancing mGluR5 activation by a positive modulator before behavioral testing rescued MWM and recognition memory of old WT mice. In addition, KOR inhibitor norBNI reduced anxiety-related behaviors in EPM task of old WT mice. Finally, at the molecular level, aging-related decrease in Arc expression, a downstream mGluR signal that has been highly implicated in spatial learning, is completely rescued in $P d y n^{-1-}$ mice. In addition, spatial learning-related Homer 1a expression in old $P d y n^{-1-}$ mice is significantly higher than WT mice. Together, our findings suggest that an increase in expression of Pdyn during normal aging plays substantial roles in aging-related cognitive and psychopathological changes. In addition, these changes could be related to a reduction in Group 1 mGluR signaling and function.

Although Pdyn has been shown to impair spatial memory formation in MWM, our findings suggest that increased Pdyn expression in aging is related to deficits in both regular and reversal spatial learning in MWM. A decline in spatial memory formation has been associated with increased Pdyn expression in 
aged rodents (Gallagher and Nicolle, 1993; Svensson et al., 2006). Indeed, direct hippocampal injection of dynorphin (McDaniel et al., 1990) or KOR agonist (Sandin et al., 1998) in adult rats impairs MWM learning. Although most of these studies focused on the impact of dynorphin on MWM acquisition during training, we compared both performances of mice during training and probe tests (long-term memory retrieval) and found that knocking down Pdyn protected aged $P d y n^{-1-}$ mice from impairments in the acquisition and retention of spatial memory. In addition, we observed no agingrelated decline in reversal MWM training and retention in $P d y n^{-/-}$mice. Finally, blocking KOR by norBNI alone improved spatial memory of old WT mice. These findings strongly support the hypothesis that increased expression of Pdyn during aging is an important molecular substrate for spatial memory impairment. Although a previous study using another Pdyn KO mouse line did not reveal better probe test performance than WT mice (Nguyen et al., 2005), this seeming discrepancy could result from the use of younger mice (13-17 months vs 18-25 months in the current study) and shorter training paradigm in that study.

We also discovered a previously unknown role of Pdyn in the decline of recognition memory in aging. Aging-related cognitive impairment in recognition memory is highly common in animal models and human (Burke et al., 2012). Although Pdyn has been implicated in stress-induced impairment of NOR, manipulating KOR activation and Pdyn expression has little effect on normal NOR in adult mice (Carey et al., 2009). Our finding that the aging-related decline in recognition memory can be rescued in $P d y n^{-1-}$ mice, together with the rescue effect of norBNI on recognition memory in old WT mice, provided, to our knowledge, the first evidence suggesting an involvement of Pdyn in aging-related NOR deficits.

Despite the seemingly well-known anxiogenic role of dynorphin, we revealed for the first time that dynorphin could be responsible for the heightened anxiety in aging. An anxiogenic role of opioid was revealed initially by the effect of an opioid receptor partial agonist naloxone pretreatment to abolish the anticonflict effect of chlordiazepoxide (Billingsley and Kubena, 1978), suggesting that the anxiolytic effect of benzodiazepine is related to blockade of opioid receptor. The anticonflict effect of benzodiazepine can be
A

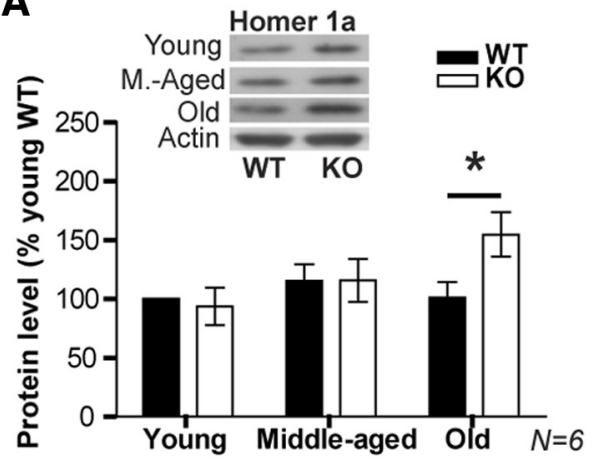

C
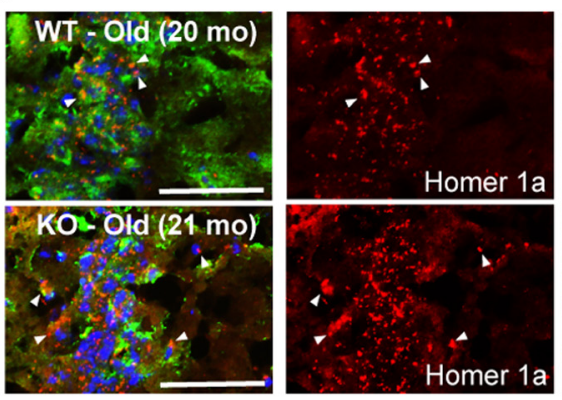

D

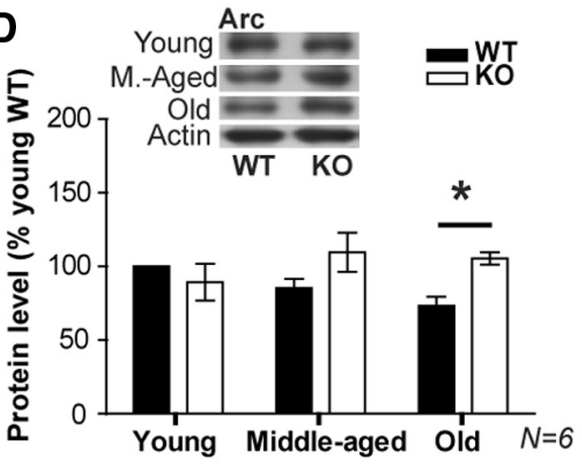

$\mathbf{F}$
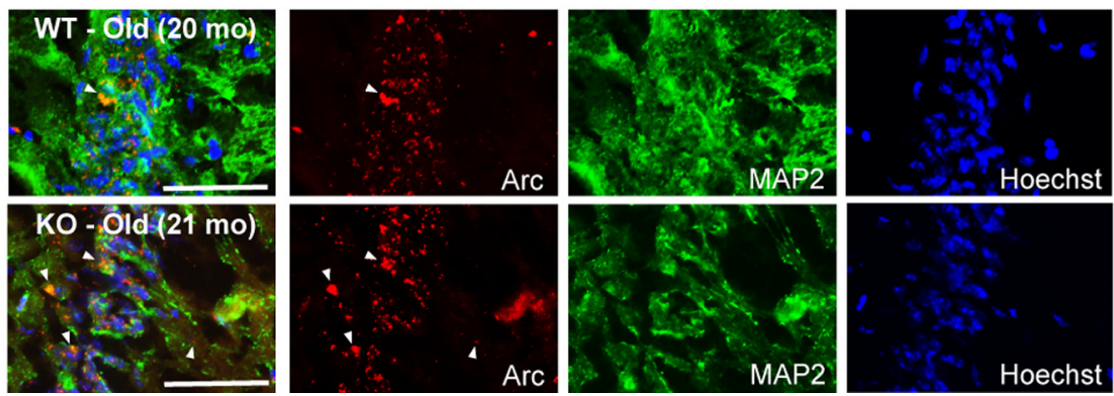

Figure 7. Immediate early gene Homer $1 a$ and Arc/Arg 3.1 expression is correlated with MWM performances. $\boldsymbol{A}$, Homer 1 a protein level was significantly higher in old $P d y n^{-1-}$ mice homogenates compared with WT animals. $\boldsymbol{B}$, Homer $1 \mathrm{a}$ expression level was significantly correlated to old mice MWM performances during probe tests. $\boldsymbol{C}$, Homer 1a double immunostaining with the neuronal marker MAP2 confirmed higher expression of this IEG in old Pdyn ${ }^{-1-}$ mice CA1 hippocampus region. $\boldsymbol{D}$, Arc protein level decreased with aging in WT mice, whereas it remained unaltered in $P d y n^{-1-}$ mice. $\boldsymbol{E}$, Like Homer 1a, Arc expression level was significantly correlated with old mice MWM performances. $\boldsymbol{F}$, Arc staining was slightly enhanced in the CA1 area of $P d y n^{-1-}$ mice hippocampus compared with WT mice. Western blot values represent mean \pm SEM from three separate experiments ( $n=6$ for each age group and genotype), and data are expressed as percentage of 6-mo WT mice. ${ }^{*} p<0.05$ (two-way ANOVA). Correlations were determined with the Pearson test. Scale bar, $50 \mu \mathrm{m}$. Arrowheads indicate IEG-positive cells. 

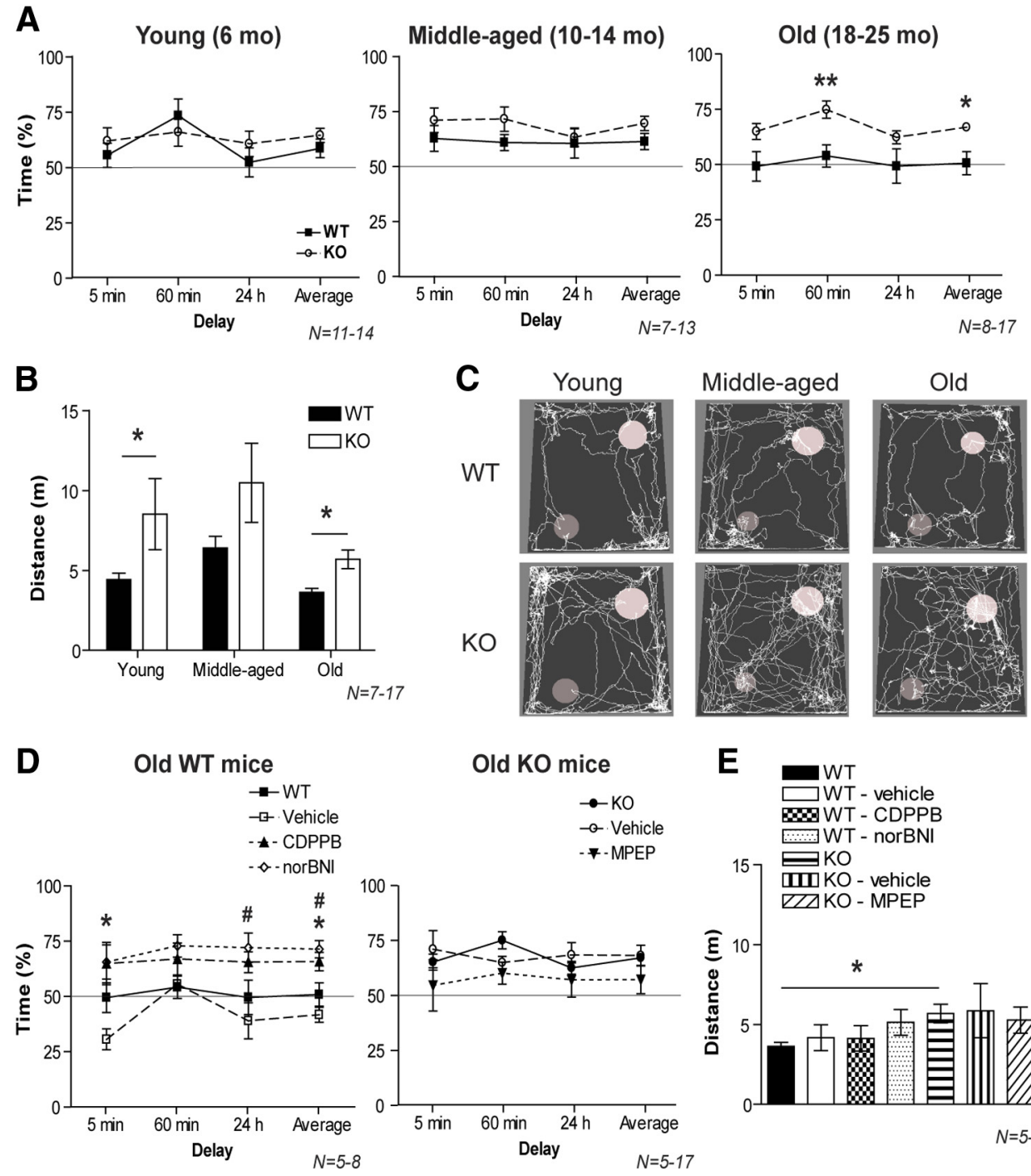

Figure 8. Recognition memory is unaffected despite aging in $P d y n^{-/-}$mice. $A$, Whereas old WT mice became memory-impaired at $18-25$ months of age, old $P d y n^{-1-}$ mice spent significantly more time interacting with the novel objects on average and after a 60 min delay. No difference was observed for young and middle-aged $P d y n^{-1-}$ mice compared with WT animals of the same age. $\boldsymbol{B}$, Pdyn $^{-1-}$ mice displayed higher exploratory behavior than WT mice. C, Representative paths for young, middle-aged, and old mice in the novel object recognition arena (novel object top right in white). $\boldsymbol{D}$, Treatment with norBNI (\#) or CDPPB $\left(^{*}\right)$ improved recognition memory of old WT mice by increasing time treated mice spent on novel objects. $\boldsymbol{E}$, Exploratory behavior was unaffected by drugs injections. Data represent mean \pm SEM for all animals of each group $(n=7-17$ for each age group and genotype for untreated mice, $n=5 /$ genotype for vehicle, $n=8 /$ drug for injected mice) trained in three different cohorts. Statistical significance was evaluated with two-way ANOVA followed by Bonferroni post tests performed between genotypes $(\boldsymbol{A}, \boldsymbol{B})$ or treated groups and untreated controls $(\boldsymbol{D})$ and one-way ANOVA for total distance traveled after pharmacological treatments $(\boldsymbol{E}) .{ }^{*} p<0.05 .{ }^{* *} p<0.01$. \#p $<0.05$.

blocked by the pretreatment of the KOR antagonist norBNI (Tsuda et al., 1996), supporting a crucial role of dynorphin signaling in anxiety. Indeed, both pharmacological (norBNI) and genetic ablation ( $P d y n \mathrm{KO}$ ) of dynorphin signals is sufficient to increase exploratory activities in the open field and the open arm of EPM (Knoll et al., 2007; Wittmann et al., 2009). In our study, we observed for the first time an anxiolytic effect of norBNI in old mice by increasing the distance traveled in the EPM open arms and overall exploratory activity of these mice (Fig. 9). Alternatively, dynorphin peptide or KOR agonists are anxiogenic (Tsuda et al., 1996; Wittmann et al., 2009; Smith et al., 2012). Although anxiety and depression in late life are risk factors for disability (Lenze et al., 2001), little is known of the underlying biological mechanisms. Using EPM and novelty-suppression of feeding, we confirmed an increase in anxiety in aged mice. Importantly, we revealed anxiolytic effects of knocking down Pdyn in both tests, suggesting an important contribution of Pdyn in aging-related increase in anxiety. $P d y n^{-1-}$ mice displayed a decrease and increase in mRNA expression of corticotrophin releasing hormone and neuropeptide Y, respectively (Wittmann et al., 2009); both changes are likely anxiolytic (Arborelius et al., 1999; Carvajal et al., 2004). Thus, the anxiogenic effect of dynorphin in aging is likely related to the interaction between these neuropeptides that regulate emotions.

mGluR5-related signals have been linked to successful cognitive aging in rodents (Lee et al., 2005; Ménard and Quirion, 2012b). Our findings that aging-related reduction of Group 1 mGluR signal and function is rescued in $P d y n^{-1-}$ mice suggest an intricate interaction between Pdyn and mGluR in aging. Indeed, the restoration of mGluR signal and function in $P d y n^{-1-}$ mice seem to be responsible for the improvement of cognitive function in these mice because blocking mGluR5 using MPEP abolished the protective effect of knocking down Pdyn on spatial memory formation and EPM performance in old $P d y n^{-1-}$ mice, and en- 
A
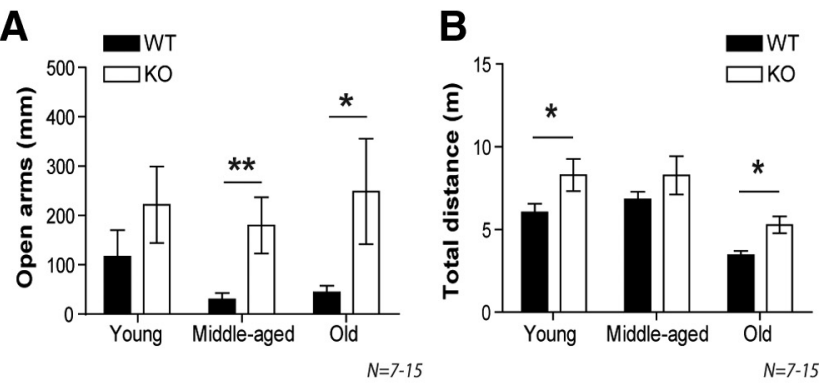

C
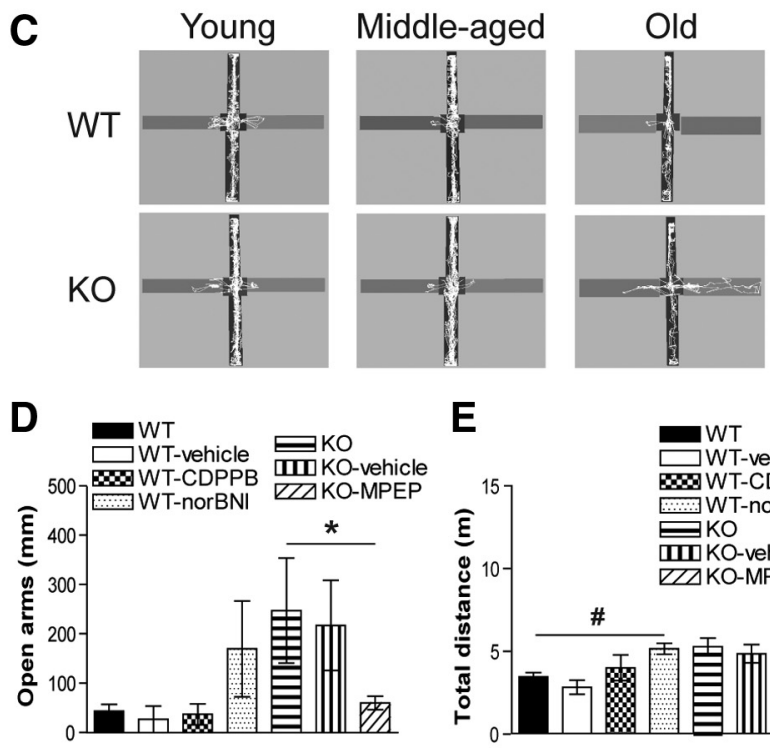

E

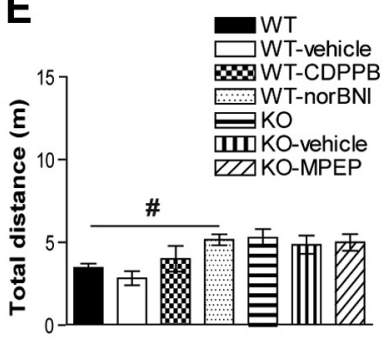

$N=5-15$

Figure 9. Anxiety-related behaviors are reduced in middle-aged and old $P d y n^{-1-}$ mice. $\boldsymbol{A}$, Middle-aged and old $P d y n^{-1-}$ mice traveled a longer distance in the EPM open arms compared with WT mice of the same age, suggesting lower anxiety. $\boldsymbol{B}$, Young and old $P d y n^{-1-}$ mice traveled a significantly longer overall distance in the EPM arena compared with WT mice of the same age, suggesting lower anxiety and higher explorative behavior in a bright environment. $\boldsymbol{C}$, Representative paths for young, middle-aged, and old WT and $P d y n^{-1-}$ mice. Black represents closed arms; gray represents open arms. D, MPEP treatment significantly decreased the distance traveled in EPM open arms for old $P d y n^{-1-}$ mice. $E$, Old WT mice injected with norBNI showed higher explorative behavior compared with old untreated WT mice. Data represent mean \pm SEM for all animals of each group ( $n=7-15$ for each age group and genotype and 5-8 for injected old mice groups) trained in three different cohorts. Two-way ANOVA followed by Bonferroni post tests was performed between genotypes and age groups, and one-way ANOVA between treated groups and controls. ${ }^{*} p<0.05 .{ }^{* *} p<0.01$. \#p $<0.05$.

hancing mGluR5 function using CDPPB alone improved spatial and recognition memory performance and reduced anxiety of old WT mice. Group 1 mGluR activation plays crucial roles in the formation of spatial (Lu et al., 1997; Balschun et al., 1999) and recognition memory (Barker et al., 2006; Christoffersen et al., 2008) that were rescued in old $P d y n^{-1-}$ mice. Indeed, positive allosteric modulator of mGluR5 alone is sufficient to promote spatial (Balschun et al., 1999) and recognition memory formation (Reichel et al., 2011). In addition, we found that expression of downstream IEG signals of Group $1 \mathrm{mGluR}$, including Arc and Homer 1a, is increased in Pdyn ${ }^{-1-}$ mice. Changes in MWM performance correlate with both Homer 1a and Arc expression, confirming the importance of these IEGs in spatial learning (Marrone et al., 2008). Homer $1 a$ is an IEG expressed after neuronal activity (Ménard and Quirion, 2012a). It acts as a dominant-negative modulator by reducing mGluR5 coupling with its signaling effectors (Kammermeier and Worley, 2007). Exposure to novelty induces the transcription of $\operatorname{Arc}$ in the hip-
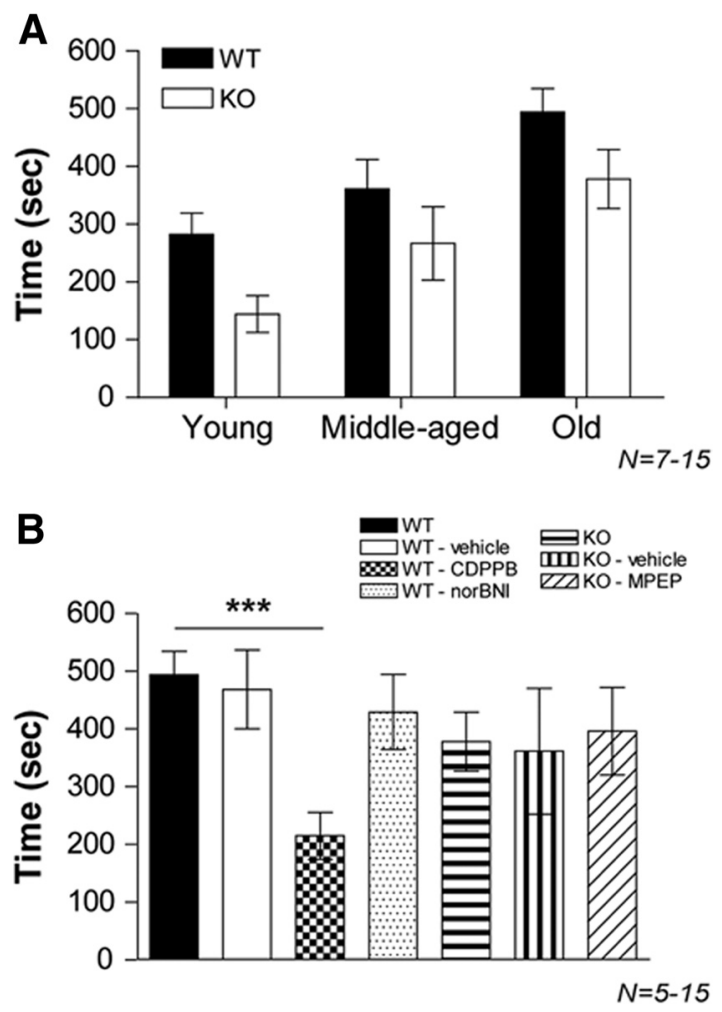

Figure 10. Anxiety induced by novelty-suppressed feeding is reduced in $P d y n^{-1-}$ mice at all ages. $\boldsymbol{A}, P d y n^{-1-}$ mice display lower anxiety by using shorter time than WT mice to reach food in the open field Thatcher-Britton task. $\boldsymbol{B}$, Treatment with CDPPB significantly reduced time to reach food of old WT mice compared with untreated animals. Data represent mean \pm SEM for all animals of each group ( $n=7-15$ for each age group and genotype and 5- 8 for injected old mice groups) trained in three different cohorts. ${ }^{* *} p<0.001$ (one-way ANOVA followed by Bonferroni post test).

pocampus (Luscher and Huber, 2010). Finally, increasing findings suggest that LTD mechanisms play positive roles in spatial (Ge et al., 2010) and recognition memory formation (Griffiths et al., 2008), suggesting imperative contribution of the rescue of mGluR-LTD in the cognitive performance of old $\mathrm{Pdyn}^{-1-}$ mice. Notably, our findings do not rule out contribution of other forms of synaptic plasticity that are induced by nonmetabotropic glutamate receptors, such as NMDA receptors. Indirect enhancement of NMDA receptor function by allosteric potentiation of mGluR5 can enhance synaptic plasticity and performance on learning and memory tasks (Ayala et al., 2009; Rosenbrock et al., 2010). Potentiation of mGluR5 activation also reverses cognitive and motivational deficits induced by NMDA receptor antagonists or drugs of abuse (Cleva and Olive, 2011). CDPPB, for example, has been shown to rescue behaviors altered by the NMDA receptor antagonist MK-801 (Darrah et al., 2008). Interestingly, in our study, treatment with CDPPB improved novelty suppression of feeding in old WT mice. Moreover, in line with the inhibitory effect of MPEP on old $P d y n^{-1-}$ distance traveled in the EPM open arms, mGluR5 KO mice showed increased anxiety with aging (Inta et al., 2013).

Although it remains unclear why aging-related decline in mGluR function is rescued in $P d y n^{-1-}$ mice, interaction between dynorphinergic and glutamatergic transmission has been supported by previous findings. Dynorphin modulates glutamatergic transmission in a regional dependent manner, so that it inhibits postsynaptic glutamate responses of the perforant path in the dentate gyrus (Wagner et al., 1993) but enhances glutamate 
release in the CA2/CA3 region of the hippocampus (Faden, 1992). Alternatively, glutamate from perforant path afferents reduces dynorphin release in the dentate gyrus (Xie et al., 1991). On the receptor level, dynorphin has been shown to decrease NMDA receptor function (Chen et al., 1995). Interestingly, Group 1 mGluR activation enhances mRNA expression of preprodynorphin (Mao and Wang, 2001). Notably, these studies were performed almost exclusively in young and adult tissue. Further studies of the interaction between dynorphinergic and glutamatergic transmission could reveal mechanisms underlying the opposing changes of these two neurotransmitter systems in aging.

In conclusion, our findings suggest that reducing Pdyn expression protects aged mice from impairment of cognition and augmentation of anxiety-related behaviors. More importantly, these protective effects of reducing Pdyn expression could be mediated by the upregulation of Group 1 mGluR expression. These results identify Pdyn and Group 1 mGluR signaling as promising targets for drug discovery to prevent age-associated cognitive and behavioral deficits in normal and pathological aging.

\section{References}

Arborelius L, Owens MJ, Plotsky PM, Nemeroff CB (1999) The role of corticotropin-releasing factor in depression and anxiety disorders. J Endocrinol 160:1-12. CrossRef Medline

Ayala JE, Chen Y, Banko JL, Sheffler DJ, Williams R, Telk AN, Watson NL, Xiang Z, Zhang Y, Jones PJ, Lindsley CW, Olive MF, Conn PJ (2009) mGluR5 positive allosteric modulators facilitate both hippocampal LTP and LTD and enhance spatial learning. Neuropsychopharmacology 34: 2057-2071. CrossRef Medline

Balschun D, Manahan-Vaughan D, Wagner T, Behnisch T, Reymann KG, Wetzel W (1999) A specific role for group I mGluRs in hippocampal LTP and hippocampus-dependent spatial learning. Learn Mem 6:138152. CrossRef Medline

Barker GR, Bashir ZI, Brown MW, Warburton EC (2006) A temporally distinct role for group I and group II metabotropic glutamate receptors in object recognition memory. Learn Mem 13:178-186. CrossRef Medline

Bedrosian TA, Herring KL, Weil ZM, Nelson RJ (2011) Altered temporal patterns of anxiety in aged and amyloid precursor protein (APP) transgenic mice. Proc Natl Acad Sci U S A 108:11686-11691. CrossRef Medline

Benoit CE, Rowe WB, Ménard C, Sarret P, Quirion R (2011) Genomic and proteomic strategies to identify novel targets potentially involved in learning and memory. Trends Pharmacol Sci 32:43-52. CrossRef Medline

Billingsley ML, Kubena RK (1978) The effects of naloxone and picrotoxin on the sedative and anticonflict effects of benzodiazepines. Life Sci 22: 897-906. CrossRef Medline

Burke SN, Wallace JL, Hartzell AL, Nematollahi S, Plange K, Barnes CA (2011) Age-associated deficits in pattern separation functions of the perirhinal cortex: a cross-species consensus. Behav Neurosci 125:836847. CrossRef Medline

Burke SN, Ryan L, Barnes CA (2012) Characterizing cognitive aging of recognition memory and related processes in animal models and in humans. Front Aging Neurosci 4:15. CrossRef Medline

Carey AN, Lyons AM, Shay CF, Dunton O, McLaughlin JP (2009) Endogenous $\kappa$ opioid activation mediates stress-induced deficits in learning and memory. J Neurosci 29:4293-4300. CrossRef Medline

Carvajal CC, Vercauteren F, Dumont Y, Michalkiewicz M, Quirion R (2004) Aged neuropeptide $Y$ transgenic rats are resistant to acute stress but maintain spatial and non-spatial learning. Behav Brain Res 153:471-480. CrossRef Medline

Chen L, Gu Y, Huang LY (1995) The mechanism of action for the block of NMDA receptor channels by the opioid peptide dynorphin. J Neurosci 15:4602-4611. Medline

Christoffersen GR, Simonyi A, Schachtman TR, Clausen B, Clement D, Bjerre VK, Mark LT, Reinholdt M, Schmith-Rasmussen K, Zink LV (2008) MGlu5 antagonism impairs exploration and memory of spatial and nonspatial stimuli in rats. Behav Brain Res 191:235-245. CrossRef Medline

Cleva RM, Olive MF (2011) Positive allosteric modulators of type 5 metabo- tropic glutamate receptors (mGluR5) and their therapeutic potential for the treatment of CNS disorders. Molecules 16:2097-2106. CrossRef Medline

Darrah JM, Stefani MR, Moghaddam B (2008) Interaction of N-methyl-Daspartate and group 5 metabotropic glutamate receptors on behavioral flexibility using a novel operant set-shift paradigm. Behav Pharmacol 19:225-234. CrossRef Medline

Dong Z, Bai Y, Wu X, Li H, Gong B, Howland JG, Huang Y, He W, Li T, Wang YT (2013) Hippocampal long-term depression mediates spatial reversal learning in the Morris water maze. Neuropharmacology 64:65-73. CrossRef Medline

Faden AI (1992) Dynorphin increases extracellular levels of excitatory amino acids in the brain through a non-opioid mechanism. J Neurosci 12:425-429. Medline

Gallagher M, Nicolle MM (1993) Animal models of normal aging: relationship between cognitive decline and markers in hippocampal circuitry. Behav Brain Res 57:155-162. CrossRef Medline

Ge Y, Dong Z, Bagot RC, Howland JG, Phillips AG, Wong TP, Wang YT (2010) Hippocampal long-term depression is required for the consolidation of spatial memory. Proc Natl Acad Sci U S A 107:16697-16702. CrossRef Medline

Griffiths S, Scott H, Glover C, Bienemann A, Ghorbel MT, Uney J, Brown MW, Warburton EC, Bashir ZI (2008) Expression of long-term depression underlies visual recognition memory. Neuron 58:186-194. CrossRef Medline

Inta D, Vogt MA, Luoni A, Filipoviæ D, Lima-Ojeda JM, Pfeiffer N, Gasparini F, Riva MA, Gass P (2013) Significant increase in anxiety during aging in mGlu5 receptor knockout mice. Behav Brain Res 241:27-31. CrossRef Medline

Jiang HK, Owyang VV, Hong JS, Gallagher M (1989) Elevated dynorphin in the hippocampal formation of aged rats: relation to cognitive impairment on a spatial learning task. Proc Natl Acad Sci U S A 86:2948-2951. CrossRef Medline

Kammermeier PJ, Worley PF (2007) Homer la uncouples metabotropic glutamate receptor 5 from postsynaptic effectors. Proc Natl Acad Sci U S A 104:6055-6060. CrossRef Medline

Kemp A, Manahan-Vaughan D (2007) Hippocampal long-term depression: master or minion in declarative memory processes? Trends Neurosci 30: 111-118. CrossRef Medline

Knoll AT, Meloni EG, Thomas JB, Carroll FI, Carlezon WA Jr (2007) Anxiolytic-like effects of $\kappa$-opioid receptor antagonists in models of unlearned and learned fear in rats. J Pharmacol Exp Ther 323:838-845. CrossRef Medline

Kölsch H, Wagner M, Bilkei-Gorzó A, Toliat MR, Pentzek M, Fuchs A, Kaduszkiewicz H, van den Bussche H, Riedel-Heller SG, Angermeyer MC, Weyerer S, Werle J, Bickel H, Mösch E, Wiese B, Daerr M, Jessen F, Maier W, Dichgans M (2009) Gene polymorphisms in prodynorphin (PDYN) are associated with episodic memory in the elderly. J Neural Transm 116:897-903. CrossRef Medline

Kotz CM, Weldon D, Billington CJ, Levine AS (2004) Age-related changes in brain proDynorphin gene expression in the rat. Neurobiol Aging 25: 1343-1347. CrossRef Medline

Lauterborn JC, Lynch G, Vanderklish P, Arai A, Gall CM (2000) Positive modulation of AMPA receptors increases neurotrophin expression by hippocampal and cortical neurons. J Neurosci 20:8-21. Medline

Lee HK, Min SS, Gallagher M, Kirkwood A (2005) NMDA receptorindependent long-term depression correlates with successful aging in rats. Nat Neurosci 8:1657-1659. CrossRef Medline

Lenze EJ, Rogers JC, Martire LM, Mulsant BH, Rollman BL, Dew MA, Schulz R, Reynolds CF 3rd (2001) The association of late-life depression and anxiety with physical disability: a review of the literature and prospectus for future research. Am J Geriatr Psychiatry 9:113-135. CrossRef Medline

Loacker S, Sayyah M, Wittmann W, Herzog H, Schwarzer C (2007) Endogenous dynorphin in epileptogenesis and epilepsy: anticonvulsant net effect via $\kappa$ opioid receptors. Brain 130:1017-1028. CrossRef Medline

Lu YM, Jia Z, Janus C, Henderson JT, Gerlai R, Wojtowicz JM, Roder JC (1997) Mice lacking metabotropic glutamate receptor 5 show impaired learning and reduced CA1 long-term potentiation (LTP) but normal CA3 LTP. J Neurosci 17:5196-5205. Medline

Lüscher C, Huber KM (2010) Group 1 mGluR-dependent synaptic longterm depression: mechanisms and implications for circuitry and disease. Neuron 65:445-459. CrossRef Medline 
Malleret G, Alarcon JM, Martel G, Takizawa S, Vronskaya S, Yin D, Chen IZ, Kandel ER, Shumyatsky GP (2010) Bidirectional regulation of hippocampal long-term synaptic plasticity and its influence on opposing forms of memory. J Neurosci 30:3813-3825. CrossRef Medline

Mao L, Wang JQ (2001) Upregulation of preprodynorphin and preproenkephalin mRNA expression by selective activation of group I metabotropic glutamate receptors in characterized primary cultures of rat striatal neurons. Brain Res Mol Brain Res 86:125-137. CrossRef Medline

Marrone DF, Schaner MJ, McNaughton BL, Worley PF, Barnes CA (2008) Immediate-early gene expression at rest recapitulates recent experience. J Neurosci 28:1030-1033. CrossRef Medline

McDaniel KL, Mundy WR, Tilson HA (1990) Microinjection of dynorphin into the hippocampus impairs spatial learning in rats. Pharmacol Biochem Behav 35:429-435. CrossRef Medline

McEwen BS (1999) Stress and hippocampal plasticity. Annu Rev Neurosci 22:105-122. CrossRef Medline

Ménard C, Quirion R (2012a) Group 1 metabotropic glutamate receptor function and its regulation of learning and memory in the aging brain. Front Pharmacol 3:182. CrossRef Medline

Ménard C, Quirion R (2012b) Successful cognitive aging in rats: a role for mGluR5 glutamate receptors, homer 1 proteins and downstream signaling pathways. PLoS One 7:e28666. CrossRef Medline

Munro TA, Berry LM, Van't Veer A, Béguin C, Carroll FI, Zhao Z, Carlezon WA Jr, Cohen BM (2012) Long-acting $\kappa$ opioid antagonists nor-BNI, GNTI and JDTic: pharmacokinetics in mice and lipophilicity. BMC Pharmacol 12:5. CrossRef Medline

Nguyen XV, Masse J, Kumar A, Vijitruth R, Kulik C, Liu M, Choi DY, Foster TC, Usynin I, Bakalkin G, Bing G (2005) Prodynorphin knockout mice demonstrate diminished age-associated impairment in spatial water maze performance. Behav Brain Res 161:254-262. CrossRef Medline

Palmer MJ, Irving AJ, Seabrook GR, Jane DE, Collingridge GL (1997) The group I mGlu receptor agonist DHPG induces a novel form of LTD in the CA1 region of the hippocampus. Neuropharmacology 36:1517-1532. CrossRef Medline

Reichel CM, Schwendt M, McGinty JF, Olive MF, See RE (2011) Loss of object recognition memory produced by extended access to methamphetamine self-administration is reversed by positive allosteric modulation of metabotropic glutamate receptor 5. Neuropsychopharmacology 36:782-792. CrossRef Medline

Rosenbrock H, Kramer G, Hobson S, Koros E, Grundl M, Grauert M, Reymann KG, Schröder UH (2010) Functional interaction of metabotropic glutamate receptor 5 and NMDA-receptor by a metabotropic glutamate receptor 5 positive allosteric modulator. Eur J Pharmacol 639:40-46. CrossRef Medline

Rowe WB, Spreekmeester E, Meaney MJ, Quirion R, Rochford J (1998) Reactivity to novelty in cognitively-impaired and cognitively-unimpaired aged rats and young rats. Neuroscience 83:669-680. CrossRef Medline
Sandin J, Nylander I, Georgieva J, Schött PA, Ogren SO, Terenius L (1998) Hippocampal dynorphin B injections impair spatial learning in rats: a $\kappa$-opioid receptor-mediated effect. Neuroscience 85:375-382. CrossRef Medline

Schwarzer C (2009) 30 years of dynorphins: new insights on their functions in neuropsychiatric diseases. Pharmacol Ther 123:353-370. CrossRef Medline

Simmons ML, Terman GW, Drake CT, Chavkin C (1994) Inhibition of glutamate release by presynaptic $\kappa 1$-opioid receptors in the guinea pig dentate gyrus. J Neurophysiol 72:1697-1705. Medline

Smith JS, Schindler AG, Martinelli E, Gustin RM, Bruchas MR, Chavkin C (2012) Stress-induced activation of the dynorphin/ $\kappa$-opioid receptor system in the amygdala potentiates nicotine conditioned place preference. J Neurosci 32:1488-1495. CrossRef Medline

Squire LR (1992) Memory and the hippocampus: a synthesis from findings with rats, monkeys, and humans. Psychol Rev 99:195-231. CrossRef Medline

Svensson J, Diez M, Engel J, Wass C, Tivesten A, Jansson JO, Isaksson O, Archer T, Hökfelt T, Ohlsson C (2006) Endocrine, liver-derived IGF-I is of importance for spatial learning and memory in old mice. J Endocrinol 189:617-627. CrossRef Medline

Tsuda M, Suzuki T, Misawa M, Nagase H (1996) Involvement of the opioid system in the anxiolytic effect of diazepam in mice. Eur J Pharmacol 307:7-14. CrossRef Medline

Uslaner JM, Parmentier-Batteur S, Flick RB, Surles NO, Lam JS, McNaughton CH, Jacobson MA, Hutson PH (2009) Dose-dependent effect of CDPPB, the mGluR5 positive allosteric modulator, on recognition memory is associated with GluR1 and CREB phosphorylation in the prefrontal cortex and hippocampus. Neuropharmacology 57:531-538. CrossRef Medline

Wagner JJ, Terman GW, Chavkin C (1993) Endogenous dynorphins inhibit excitatory neurotransmission and block LTP induction in the hippocampus. Nature 363:451-454. CrossRef Medline

Wittmann W, Schunk E, Rosskothen I, Gaburro S, Singewald N, Herzog H, Schwarzer C (2009) Prodynorphin-derived peptides are critical modulators of anxiety and regulate neurochemistry and corticosterone. Neuropsychopharmacology 34:775-785. CrossRef Medline

Xie CW, McGinty JF, Lee PH, Mitchell CL, Hong JS (1991) A glutamate antagonist blocks perforant path stimulation-induced reduction of dynorphin peptide and prodynorphin mRNA levels in rat hippocampus. Brain Res 562:243-250. CrossRef Medline

$\mathrm{Xu}$ J, Zhu Y, Contractor A, Heinemann SF (2009) mGluR5 has a critical role in inhibitory learning. J Neurosci 29:3676-3684. CrossRef Medline

Yakovleva T, Marinova Z, Kuzmin A, Seidah NG, Haroutunian V, Terenius L, Bakalkin G (2007) Dysregulation of dynorphins in Alzheimer disease. Neurobiol Aging 28:1700-1708. CrossRef Medline 